\title{
A Post Implementation Review of the Success of an e-Government Portal Project
}

MIM592 RESEARCH PAPER

\section{BY}

\section{ENKHZUL GOMBODORJ}

Student ID: 300191119

Supervisor: Dr. MARY TATE

Submitted to the School of Information Management,

Victoria University of Wellington

in partial fulfilment of the requirements for the degree of

Master of Information Management

Date: 11 November 2011 


\section{Table of Contents}

$\begin{array}{lr}\text { Preface } & 3\end{array}$

Abstract 4

Section 1. Introduction 5

1.1 Background 5

1.2 Context of the Study

1.3 Current and Future e- Government Portals in Mongolia 11

1.4 Research Question $\quad 15$

1.5 Research Benefit 15

Section 2. Literature Review 16

2.1 Key concepts 16

2.1.1 E-Government 16

2.1.2 E-Government Portal 22

2.1.3 Information System Success 28

Section 3. Research Methodology 35

3.1 Research Method 35

3.2 Sample Selection 36

3.3 Data Collection 37

3.4 Data Analysis Procedures 38

Section 4. Data Analysis 39

4.1 Interview Findings 39

4.2 Additional factors $\quad 53$

Section 5. Discussion $\quad 58$

Section 6. Recommendations

Section 7. Research Limitations

Section 8. Conclusion $\quad 66$ 


\section{List of Figures}

Figure 1. Mongolian e-Government Portal, PMIS 12

Figure 2. Examples of Performance Measures Relevant 18

to the Different e-Government Definitions

Figure 3. The Layne and Lee Model 20

Figure 4. Dimensions and Stages of e-Government 22

Portal Development in Mongolia

Figure 5. One Single Window to Access All Kinds of 23

Public Services

Figure 6. Comparison of e-Portals 26

Figure 7. Delone \& McLean IS Success Model 29

Figure 8. The 3-D Model Expanded 31

Figure 9. Success Factors and Identifying Researchers 32

Figure 10. Underlying Philosophical Assumptions 35

Figure 11. Significant Factors Identified by Interviewees 39

Figure 12. Mongolia - Internet Users 54

Figure 13. Mongolia - Personal Computer 54

Figure 14. Mongolia - Broadband Internet 55 


\section{Preface}

This report is not confidential.

I wish to offer thanks foremost to my supervisor Dr. Mary Tate, for her invaluable support and her guidance to help me to finish my research; I really appreciate how my supervisor supported me and the role she played was so incredible. I also want to thank the MIM program for giving me such a great chance and opportunity to enhance my knowledge and experience at Victoria University of Wellington. It will be a life-long memory and it has been a great experience for me study at VUW. Overall, the study helped me to discover new sides of myself and gave me a great opportunity to learn more of technological changes and their implications for society. I would be happy to apply the knowledge and experience that I gained at MIM, VUW with full confidence in the work environment back home.

To all those who participated in the interviews, I deeply appreciate their time and thoughtful conversation which required time and dedication on their part.

At last, I would like thank for my family and friends who supported me along the way.

I certify that except as noted above, the report is my own work and all references are accurately reported.

\section{Enkhzul Gombodorj}




\begin{abstract}
The government of Mongolia wants to improve and expand e-Government initiatives. The Government believes that the introduction of e-Government can significantly:

- improve transparency and efficiency in administration;

- increase participation of citizens in the government decision-making process;

- improve national competitiveness;

- upgrade capacity of the national ICT infrastructure;

- $\quad$ enhance the quality of civil services (Sambuu, Tudevdagva, \& Erdene, 2008)
\end{abstract}

The use of information communication technology in the public sector requires a clear vision, to deliver open and transparent government, along with improved integrated information and service delivery.

With democratic government only emerging in Mongolia in the past twenty years, there is little or no historical precedent for any type of e-Government projects, although foundations for the concept were laid in 2005, with the formation of the Information and Communication Technology Agency (ICTA), with its focus on ICT policy and project implementation. Measuring the performance of e-government initiatives in the country would be important for helping the government and public to understand what progress is being made with the development of those initiatives, and in explaining any obstacles to progress. This study focused on illustrating success factors of the e-government initiative in the country in the case of PMIS (Public Management Information System) in Mongolia. A government portal is one of the key priority e-government initiatives in every country to achieve its e-government goals, whereas the government of Mongolia started its own e-government portal in 1997.

The IS Success Model (Delone \& McLean, 1992) and the 3D Model of IS Success (Ballantine et al, 1996) were used to investigate the possible factors for the success of the PMIS portal initiative. Distance semi-structured interviews of five participants from public agencies were conducted. The result suggests a positive perception of ten success factors, which may help to increase the benefit and consequence of e-government uptake. 


\section{Section 1. Introduction}

\subsection{Background}

Governments all around the world are recognizing the importance of enabling government information and services to be open and more accessible to their citizens through online means. It has been called "e-government", one definition is 'the use of ICTs, and particularly the Internet, as a tool to achieve better government.' (Grönlund \& Horan, 2005)

Well identified goals and projects can bring a successful implementation of e-government outcomes for that country. One of the potentially identified best practices and projects to assist the governments to achieve the e-government outcome at a national level in many countries has been an e-government portal project. A government portal brings transparency and accountability to enhance the level of public trust and legitimacy online. (Gant \& Gant, 2002) It is a place where 'citizens should be able to do everything they have to do or want to do with their government' (Fang, 2002, p. 12).

A variety of evaluation methodologies exist to measure progress and to make sure identified projects are meeting the government's expectations and the pre-determined goals of egovernment, such as a transaction cost approach, which uses segmentation methods to calculate the use and benefits to different user groups, a net present value approach, which examines monetary values, and a cost effectiveness analysis which focuses on achieving specific goals in a relation to marginal costs. (Foley \& Alfonso, 2009).

Information system success measures also play a critical part to evaluate the project investment's worth. The 'measurement of information systems success or effectiveness is critical to our understanding of the value and efficacy of information system management actions and IS investments.' (Delone \& McLean, 2003).

This IS success has been studied for many decades. Some of the most well recognized IS success models include the IS Success model of Delone \& McLean (1992, 2003), the IS Impact Measurement model of Gable, Sedera \& Chan., (2008), and the 3-D model of information systems success of Ballantine et al., (1996). 
These success models are very well designed and studied for researchers and experts to perform the evaluation on an information system's performance and e-government. $\mathrm{Hu}$, Xiao, Pang \& Xie, (2005) developed an e-government project success appraisal model based on Delone \& McLean's model; Gil-García \& Pardo, (2005) also utilize the IS success models to determine various dimensions of an e-government outcome. Therefore, the multi-faceted concepts and models of IS success are well suited to be used to evaluate the e-government portal outcome in Mongolia because of its complexity and the coverage of various dimensions and areas of the phenomenon. (Delone \& McLean, 2003)

This study applies both the Delone \& Mclean and the Ballantine 3D models of IS success to explain the phenomenon, which is a study of applied theory on one hand, and on the other hand the study is explaining success factors according to policy decisions actually made in the country as well, which refers to policy research study. (Robey \& Markus, 1998) 


\subsection{Context of the Study}

Mongolia is a landlocked country with a sparse population of around 2.7 million (NSO), a small economy with a reported GDP of US\$11bn, ranking it $148^{\text {th }}$ in the world (CIA), and an underdeveloped infrastructure and inefficient ICT management. It is a democratic country that comprises twenty one provinces and covers $1566,5 \mathrm{sq} . \mathrm{km}$ of land area. These factors present significant challenges to the development of vibrant and competitive government service delivery and government information dissemination through online mechanisms. (Sukhbaatar \& Odgerel, 2005)

The government of Mongolia believes in technology potential that can enable public administration to change, to allow a for better harmonization of documents and processes, elimination of duplication, cutting of inefficient costs, and improved transparency of government processes. E-government has been pursued by the government of Mongolia since 2005, when the former Ministry of Infrastructure was restructured into the Information Communication Technology and Post Authority (ICTPA).

In order to develop national competitiveness and enhance the quality of public services, the eGovernment Master Plan of Mongolia, which had been adopted in 2005, defines the following main objectives:

- Upgrading public service quality

- Sustaining stable/high economic growth

- Conduct human development policy

- Improving living standards

- Reforming regulations (ICTA, 2005)

Changing the current paradigm of the government model into one of citizen driven, shared services, enduring relationship, immediate customer services and intelligent reporting, (ICTA, 2005), the e-government project needs to identify its priority initiatives that would assist the government to achieve these goals.

The master plan (2005) identifies several essential government-to-citizens (G2C), government-to-businesses (G2B), and government-to government $(\mathrm{G} 2 \mathrm{G})$ projects under 
ICTPA regulation, such as within G2C policy and strategies, with the following identified as the four most highly recommended projects:

1. a government representative portal

2. a passport management system

3. a real estate registration system

4. a social insurance system (Sambuu et al., 2008)

Other service areas considered for e-government provision include basic welfare, education, labour, tax affairs, immigration and trade, real-estate and authorization, all being projects that are intended to improve public services, which both businesses and citizens often use and are increasingly looking for those services to be online. (ICTA, 2005)

The Government citizen internet portal (a government representative portal) is one of the highly prioritized e-government projects for a newly established government agency to implement through public private partnership. Therefore, the government announced a tender on providing the government representative portal along with the design and construction of a Government virtual private network (VPN) and a Government Intranet, under a public private partnership model in January 2011. The "Citizen Internet Portal, Government Administrative Intranet and Virtual Private Network" document announcing the project tender for the portal states that ' ...this project, Citizen Internet Portal, Government Administrative Intranet and VPN (collectively designated as the Portal System) is aligned with ICTPA's strategic objectives of utilizing ICT to improve the quality and efficiency of government.' (Information Communication Technology and Post Authority, 2010) The procurement process is intended to select the best private partner to deliver the project successfully, cooperating with Government. (Information Communication Technology and Post Authority, 2010).

Can this project be delivered successfully? What factors may impact the implementation of the project? In order to identify potential success factors of the proposed portal, the current portal system need to be evaluated to illustrate the possible success factors and challenges. Also, e-Government projects need to be a continuation of the previous initiatives, and have to learn from the past to leverage previous experience. 
Sambuu et al., (2008) identified the following top ranked Mongolian Government websites:

- www.mta.mn (Mongolian National Tax Administration),

- www.pmis.gov.mn (official website of the Governments organizations of Mongolia)

- www.legalinfo.mn (Legal information system),

- www.mongolbank.mn (Bank of Mongolia),

- www.open-government (Open Government)

The Public Management Information System (PMIS) has been one of the most highly recommended and attractive government portals in Mongolia, and incorporates over thirty organizations, 11 ministries and 20 agencies and other institutions. (Sambuu et al., 2008) Since the system was launched in 1997, the system and project have helped public servants to learn first level information communication technologies, such as how to use computers and common business applications such as Word, Excel and Power Point. More than 150 computers have been connected through a local area network (LAN) for only one organization.

The PMIS has been a favourite with the public since its introduction, despite its recognized shortcomings. Assessing its success factors and challenges will assist the government to grow and achieve its future e-government goals. The study, the post implementation review of the current e-Government portal, can provide valuable information for future e-government projects to run smoothly and successfully. If lessons are not recognized from previous experience, there is an increased risk that the majority of e-government-for-development projects tend to fail either totally or partially. (Heeks, 2003) Also, e-Government projects present different types of challenges for their development, such as information and data quality, information technology infrastructure, legal and regulatory issues and a lack of alignment of organizational goals and project challenges. (Gil-García \& Pardo, 2005)

'Portals are single-point web-browser interfaces used to promote the gathering, sharing and dissemination of information as well as the provision of services to communities of interest.' (Detlor \& Finn, 2002). They are designed to enable information transfer, to interact with citizens, or enable the making of transactions, or they may simply allow citizens to get as much information as they want, depending on their precise purpose. Overall it is considered 
as a single gateway for government to share and deliver information and public services to users via the Internet. 


\subsection{Current and Future e-Government Portals in Mongolia}

\section{Current - PMIS (Public Management Information System)}

The current Mongolian e-government portal is named PMIS (Public Management of the Information System), which has been established since 1997 under the ICT for Sustainable Human Development project of United Nations Development Programme (UNDP), reference number MON97/122. The project aimed to create an integrated information system to help the public officials to improve their work efficiency through the development of information communication technology. (Davaakhuu \& Delgermaa, 2000)

Due to this project's implementation, equipment had been installed to help the government officials to get information, share information, and disseminate information between their departments. Employees are also enabled by the system to access email and local government information databases through PMIS.

The coverage of the portal was not big in terms of its connectivity, which integrated around 40 agencies and public departments under one umbrella, and is located at http://pmis.gov.mn. (Sukhbaatar \& Odgerel, 2005)

A PMIS project delivery document (Davaakhuu \& Delgermaa, 2000) includes some statistics of PMIS usage across the several govenrment departments, such as the users'purpose of use of the system, users satisfaction with the system. The document reports that users knowledge about the system was low, where the majority of the users did not know what the system is used for, with $25 \%$ of the respondents believing it to be the government internet network, and $27.2 \%$ saying that the system is the e-government local e-mail system. However, usage of the system was quite high, even though there were complaints about the system, such as where its information was out of date, users' skills and training were low, and network speed is limited. (Davaakhuu \& Delgermaa, 2000) 


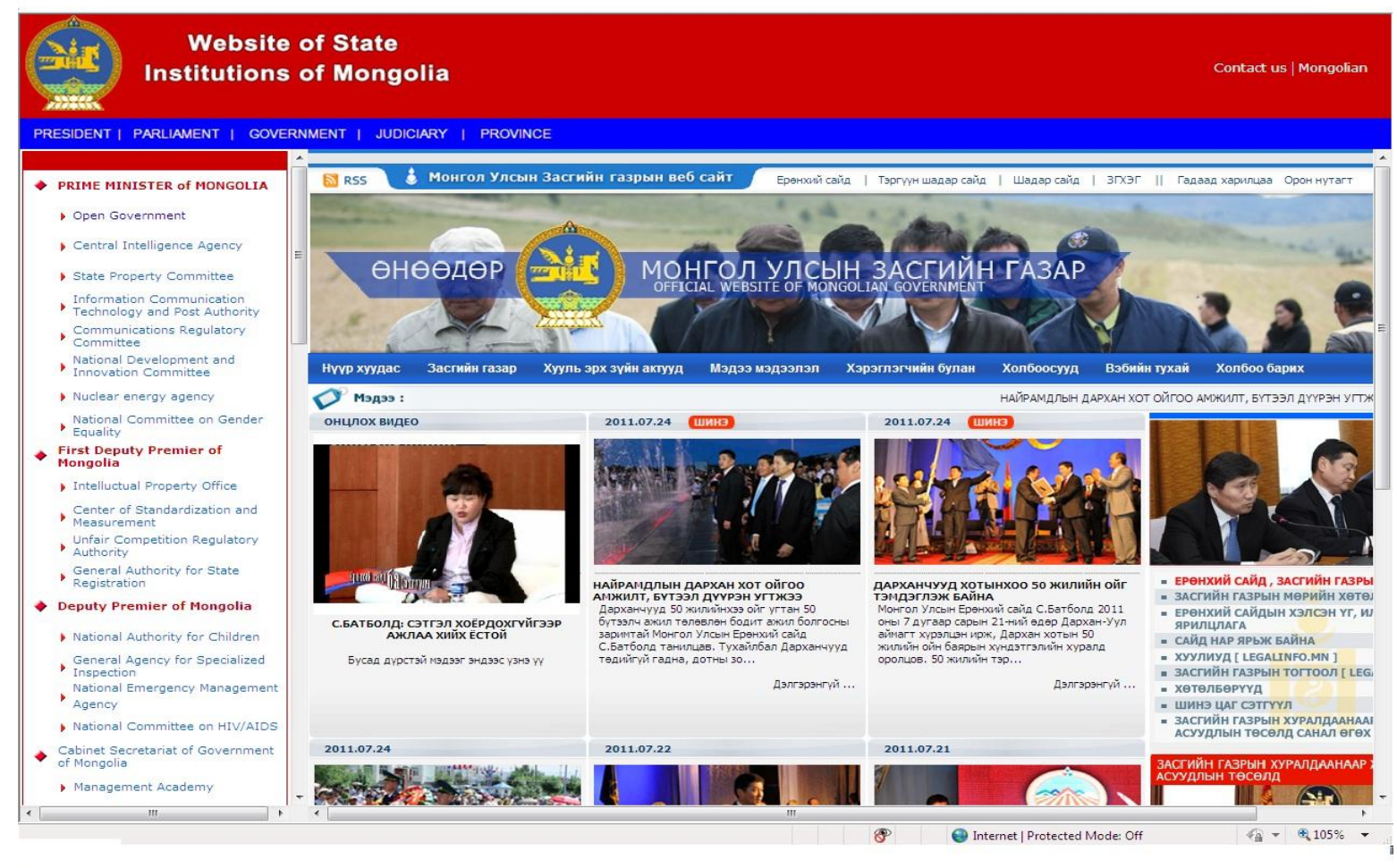

Figure 1. Mongolian e-Government Portal PMIS.

The PMIS portal information output consists generally of information related to government departments' website address and links. Once you click in any government department webpage, the portal directly brings you the website content into its own front-page. The website is designed to show and to enable the user to navigate around specific departments' information on this website, without the need to open a new browser session or tab, or to enter a new URL. Instead, the page allows users to just surf around all government agencies' web pages in one frame, by clicking on departments' addresses listed in the left side of the portal.

\section{Future - Citizen Internet Portal}

Since national ICT strategies and e-government plans have been changed dramatically in 2005 by the Information Communication Technology and Post Authority (ICTPA), they have set several ambitious e-government goals and projects. Under the e-government master plan of 2005, the ICTPA is trying to implement a new e-government portal initiative with the help 
of funding from the World Bank. The Citizen Internet Portal project is under its bidding procedure where it needs to select the best available and most responsible private partner for this challenging project.

The latest Citizen Internet portal wishes to deliver the following features:

1. Expand business and Citizen Internet Portal access to government services and information.

2. Make it easy and convenient for these groups to conduct transactions with Government on-line.

3. Enable citizen participation and feedback using Web 2.0 tools.

4. Accelerate the development and delivery of quality, on-line government services.

5. Improve the level of customer service from Government.

6. Minimize the cost to taxpayers for development and deployment of on-line transactions with Government.

7. Provide Mongolian businesses with a greater presence on the Internet. (Government Document, 2011)

This portal is targeted to connect around 70 official agencies of Mongolia. The portal will help to characterize the country, deliver services and information to citizens and businesses, and to integrate public departments, delivering e-government interaction of $\mathrm{G} 2 \mathrm{C}, \mathrm{G} 2 \mathrm{G}$ and G2B types.

The Mongolian Citizen Internet Portal wants to allow citizens to perform transactions over the portal. It plans to build the core infrastructure portal that will allow interaction at government-to-citizen (G2C) and government-to-business (G2B) levels. Simply, the central site will pull out all the comprehensive information and forms from departments, citizens can download them and subsequently submit forms and applications online. As it is described in the technical requirements of the 'Citizen Internet Portal, Government Administrative Intranet and Virtual Private Network' tender document, its main goals are as follows:

- Creation of a common, template-based web front-end to agency applications and services to enable a "common look and feel" which is consistent across all agency services. The front-end will accept user data entry and then submit the information to the agency applications as required by each agency. 
- Sending and receiving of documents from members of the public and persons who are regulated by a government of Mongolia agency.

- Receipt and processing of applications for licenses, permits etc; receipt and processing of documents for filing, and enable the building of a central authentication system for common government of Mongolia applications to reduce the need for duplicate data entry for such applications by users of the Portal.

- Establishment of an on-line payment system to the Government for the receipt of payments from the public and persons who represent a Mongolian government agency. The preferred online payment system would include functionalities relating to:

(i) bank transfers from one account to another

(ii) use of credit and debit cards

(iii)cash payments that can be deposited in payment centers

(iv)prepaid cards, and

(v) mobile payments (Government Document, 2011)

Thus, e-government projects, especially the government's Citizen Internet Portal, will allow government to achieve their e-government goals and strategies that can bring ease of public service delivery, improvement in its quality, and the supporting of online transactions, all of which will lower the overall administration cost. 


\subsection{Research Question}

The primary objective of the research is to identify success factors that would impact the potential of e-government project outcomes. The research question for this study is:

\section{What factors have contributed to the success of an e-Government portal (PMIS) project in Mongolia, and what challenges have been identified?}

\subsection{Research Benefit}

The research findings can contribute to the available research studies made around these potential success factors of e-government adoption, and to the improvement of the best practices applied to development of e-Government in Mongolia. Some challenges and areas for improvement can also be identified. 


\section{Section 2. Literature Review}

\subsection{Key Concepts}

Three distinct concepts are central to this study, e-government, the e-government portal and the wider area of the measurement of success of new information systems. The three concepts are considered in turn.

\subsubsection{E-Government}

To become a strong competitor in the global economy, any country needs to realize the importance of ICT usage for governments across a broad range of functions. Even though businesses, government and people should realize the needs of a growing, fast changing, and complex process of integration of information technology, it is equally important that it is presented as an everyday and useable tool. The Mongolian government considers that '...eGovernment improves the quality of civil service and provides transparent and efficient administration service based on knowledge with an expansion of ICT infrastructure and integration of information system.' (Ulziikhutag \& Sukhbaatar, 2006)

With successful implementation of e-government strategies, Mongolia has been ranked in $53^{\text {rd }}$ place for its e-government development index in 2010 by the United Nations, compared to $82^{\text {nd }}$ place in year 2008.(UN, 2010)

By classification of economy indexes, such as gross national income per capita, geographic region and lending group, Mongolia is considered a lower middle income economy by the World Bank. How important is e-government development for a middle income economy and developing country like Mongolia? Ndou (2004) determines that economists have found evidence that there is great potential for a relationship between ICT investment for both public and private sectors, and GDP growth. Ndou shows examples of OECD (2002) research papers where over a number of national economies, $0.5-1.3 \%$ percent of economic growth has been accounted for by the impact of ICT investment over the period 1995-2000, (Ndou, 2004). 
In addition, Chadwick (2006) illustrates that, ' ...e-government, if implemented properly, can improve current government services, increase accountability, result in more accurate and efficient delivery of services, reduce administrative costs and time spent on repetitive tasks of government employees, facilitate greater transparency in the administration of government, and allow greater access to services due to the around the clock availability of the internet.' (p.179). His definition of e-government suggests that the usage of ICT in government can enable managerial and administrative reform, involving cost reduction, improved coordination and effectiveness, and democratization of public sectors in terms of faster delivery of service and information.

Moreover, the World Bank defines e-Government as:

the use of information and communications technologies by governments to enhance the range and quality of information and services provided to citizens, businesses, civil society organizations, and other government agencies in an efficient, cost-effective and convenient manner, making government processes more transparent and accountable and strengthening democracy. (IPPP, 2009)

Whereas, the OECD has defined e-Government as a The use of ICTs, and particularly the Internet, as a tool to achieve better government "(Grönlund \& Horan, 2005). 
Grönlund and Horan (2005) illustrated four main defnitions of areas of e-Government which they propose are more significant in terms of outcome and result, rather than just activities involved .

\begin{tabular}{|l|l|}
\hline Definition & Example measures \\
\hline $\begin{array}{l}\text { Internet (online) service delivery and other } \\
\text { Internet-based activity }\end{array}$ & $\begin{array}{l}\text { online presence, } \\
\text { cost cuts, } \\
\text { access }\end{array}$ \\
\hline $\begin{array}{l}\text { E-government is equated to the use of ICTs in } \\
\text { government. While the focus is generally on } \\
\text { the delivery of services and processing, the } \\
\text { broadest definition encompasses all aspects of } \\
\text { government activity }\end{array}$ & $\begin{array}{l}\text { Procified tasks, e.g., service } \\
\text { deliver }\end{array}$ \\
\hline $\begin{array}{l}\text { E-government is defined as a capacity to } \\
\text { transform public administration through the } \\
\text { use of ICTs or indeed is used to describe a } \\
\text { new form of government built around ICTs. } \\
\text { This aspect is usually linked to Internet us }\end{array}$ & $\begin{array}{l}\text { implementation of strategy, } \\
\text { degree of political control over } \\
\text { "better government }\end{array}$ \\
$\begin{array}{l}\text { public administration } \\
\text { improved interaction with } \\
\text { business and industry, } \\
\text { increased transparency, } \\
\text { reduced corruption }\end{array}$ \\
\hline
\end{tabular}

Figure 2. Examples of Performance Measures Relevant to the Different e-Government Definitions (Source: Grönlund \& Horan, 2005)

As shown in the table, e-government is not the issue of how the performance areas are large but it is also issue of their values for government. 
Moreover, the advantages and opportunities of e-Government can include:

- Lower overall administrative costs to government

- Providing more efficient government operations

- Creating a stronger and closer relationship between citizens and government

- Providing easier access to government for all

- Improving the level of service to citizen

- Allowing greater access to decision-making

- Empowerment of citizens

- Providing more transparency in government with more responsibility. (Fahnbulleh, 2005)

Within the e-government area and from the above discussion, it becomes clear that effective implementation of e-government can bring enhanced and qualified government information and services to different types of social aspects through Government to Citizens (G2C), Government to Business (G2B), Government to Employee (G2E) and Government to Government (G2G) interactions (Saldhana, 2007).

However, according to the literature, in order to reach and take advantage of e-government adoption, governments need to be aware of the different types of development stages for egovernment initiative. 
Layne \& Lee (2001) presented a four staged e-government development maturity model every stage outlines how traditional public administration could transform, as they progress towards an increasingly internet-based government structure.

1. The cataloguing stage is the first level which, because of the public's basic demand, the government creates a non-transactional website which will have access to essential information on departments, and one which citizens can easily surf through via the internet, easily learning basic government policies and procedures. In this stage, websites 'will increase citizens' convenience and reduce the workload on frontline employees'. (Layne \& Lee, 2001) Typical functions of the website can include simple description of departments and their functions, as well as presenting information on government services, perhaps sorted by different activities that can be represented as portals.

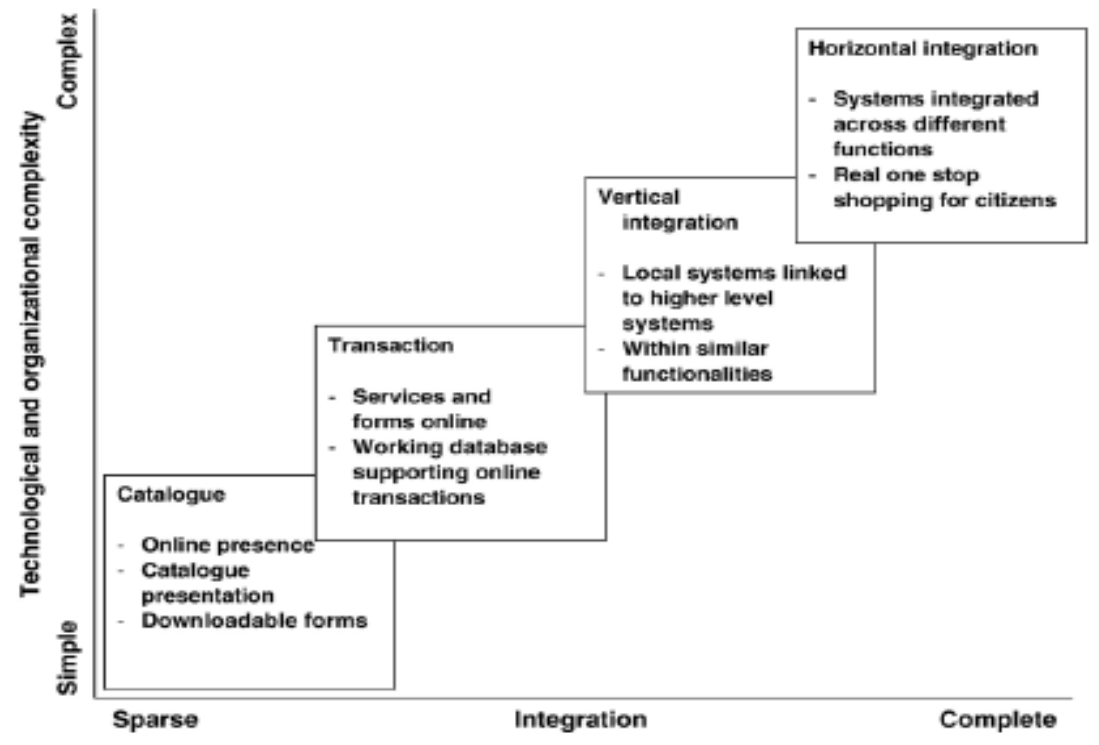

Figure 3. The Layne and Lee model: Dimensions and stages of e-Government development.

2. The second stage is a transaction stage, which requires a transformation in process from government departments, in which they deliver government services efficiently, bringing them closer to the user. Government departments allow citizens to deal with them via online communication at any time, improving the level of convenience to the user. Citizens transact with the government online by filling out forms and the 
government department responds by providing confirmations, receipts, etc., (Layne \& Lee, 2001).

The researchers suggest that in this stage, government service forms and applications need to be completed interactively online, rather than simply making it available for download and printing.

'More importantly, the citizen-customer enters through a portal that looks at the service needs of the customer as opposed to requiring the citizens to traverse numerous sites to find the information needed. This one stop on-line help center will be available through a portal, similar to that developed by the federal government through its FirstGov.gov http://www.firstgov.gov' (Layne \& Lee, p. 129)

3. The third stage is vertical integration, where government services and processes are transformed rather than concentrating on just digitizing government services as in the second stage., Layne \& Lee (2001) further stated that 'at stage three federal, state and local counterparts systems are expected to connect or, at least, communicate with each other' (p.130).

4. The fourth stage of the growth model is one where horizontal integration allows citizens access to integrated services across different government departments. The fourth stage is about pulling out information and services to citizens based on their needs from across different functions of government. Reaching this level needs more investigation and study, with security and privacy becoming main concerns once it gets to this revolutionary stage. Leadership and managerial ability are important for encouraging citizens to engage in government service delivery at this stage. This level requires leaders to deal with multi-agency cooperation challenges that could involve engaging stakeholders, monitoring progress, data structure, political support, helping agencies to define their goals and visions, legacy systems integration and so forth. 
Based on the literature review, the current and future e-government portals of Mongolia exist at the following stages of the e-government maturity development model of Layne \& Lee.

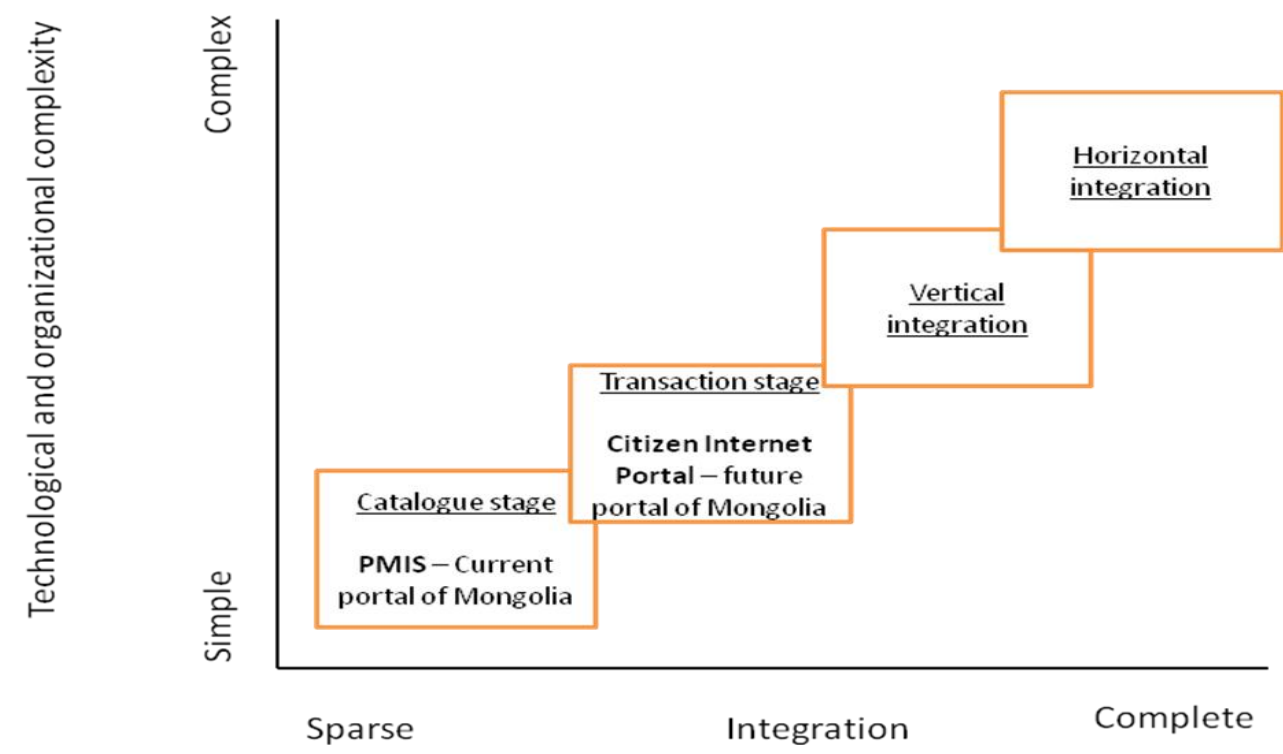

Figure 4. Dimensions and stages of e-government portal development in Mongolia based on The Layne and Lee model.

\subsubsection{E-Government Portal}

Nowadays, most governments around the world represent themselves to the world through an online presence, but also most importantly for their citizens and businesses, they provide access throughh convenient, easy to navigate, service-delivery and information-dissemination one-stop government portal websites. Hagedorn (2000) defines portals as 'single-point webbrowser interfaces used to promote the gathering, sharing and dissemination of information as well as the provision of services to communities of interest'. Moreover, 'in online one-stop government, access to public services is realized through a governmental portal'. (Wimmer, 2001)

Once broadband penetration of a country increases from year to year, governments' intention to effectively distribute their services and information online is also increasing. For example, 
Criado \& Ramilo (2003) illustrate how the internet users' numbers increased up to 580 million in May, 2002 compared to 407 million in November 2000. At the same time, they showed how government websites increased around the world from 1,915 to 10,000 by the end of 2001.(Criado \& Ramilo, 2003)

What is the importance of an e-government portal? Dongier (2003) suggests that 'an eGovernment portal is potentially a powerful tool for administrative reform and anticorruption, which enables more client-oriented, transparent, accountable, effective, efficient, and empowering government.'

Government representative portals are not generic websites that exist separately in different departments. They are instead a website purpose-built by a country's government to unite all their government related information and services in one place. Wimmer's (2001) research demonstrates the structure of this kind of portal:

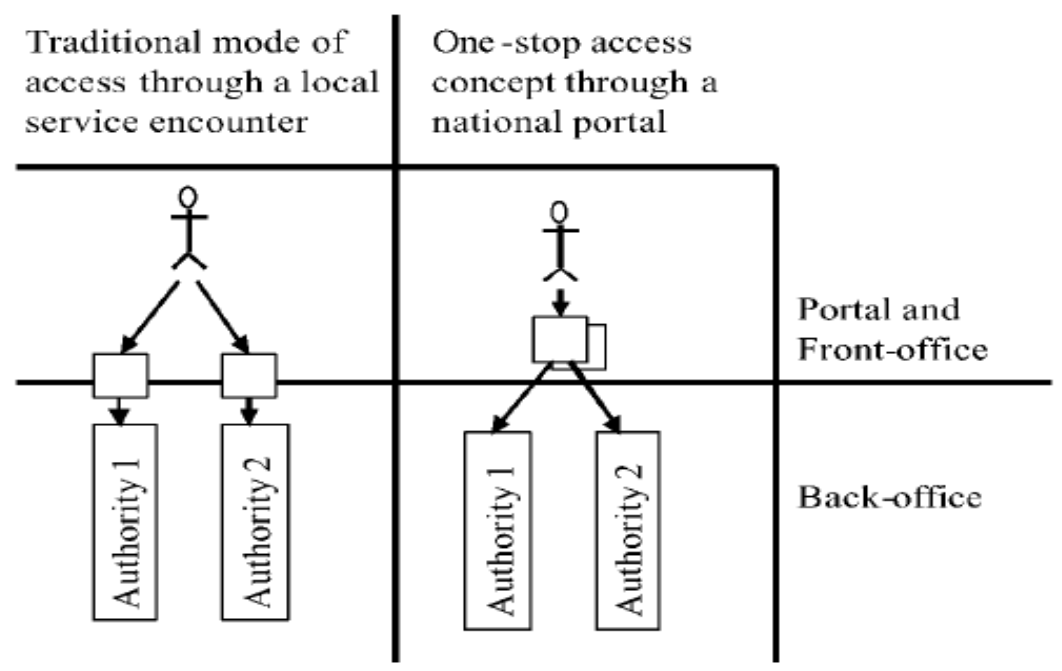

Figure 5. One single window to access all kinds of public services (Wimmer, 2001)

There is no doubt that e-Government initiatives and goals, such as information dissemination and government service delivery, can be achieved through these e-government one-stop portals, as mentioned in the earlier section of the research, and as demonstrated by the Layne \& Lee model. 
For example, a government portal initiative can exist in any of the e-government maturity stages of the Layne \& Lee model. However, portal development will largely depend on what kind of web site the government wants. Therefore, categorization can be presented by referring to the maturity model stages, or otherwise by following Criado \& Ramilo (2003), who characterized a typology of four development stages of websites in terms of level of interaction between government agencies or private agents:

1. One way websites where government agencies distribute and disseminate information in one direction, such as history, socio-economic information, tourism highlights, museums, town access plans and flag. These types of sites do not require feedback from citizens or any transaction capability

2. Two way websites. These websites involve interaction from both sides, with citizens and government able to exchange their information. Information offers more issues about functions and services; however, it is not possible to deliver online. (p.211)

3. Processing websites. At this level requests for service can be submitted online and subjected to basic editing and validation before being stored for offline processing' (p.211), suggesting that a process is more important where it requires a citizen-centric approach, rather than focusing on which department is providing what services so for example, renewing licences and paying bills may be the main services in this type of website.

4. Transaction websites. This stage is an expression of a portal which collects together all government websites and integrates a complete range of services. 'It is this fourth, transactional, stage which will have the most impact on service delivery, both in terms of greatly enhanced access and functionality for citizens, and the restructuring of government departments.' (p.212)

However, although this classification is in terms of their website development, governments can evaluate where their own e-government portal is, to monitor and assess initiatives in the context of its current status, where it has to go and how that level can be achieved. In contrast, as previously mentioned in the e-government section of this research, the eGovernment maturity model of Layne and Lee (2001) is a broader concept where 
governments can evaluate and assess how their e-government initiative is valued in terms of an e-government development vision, where it is needed to go and how it affects cross government functions.

Many governments all around the world have their own e-government portals where content and design of portals are classified by their own specific interests and needs. For example, the New Zealand e-government portal (http://newzealand.govt.nz/) is classified by its government agencies names from A-Z, its services such as "Business, Finance and Tax", "Economy, Industry and Trade", "Social Welfare and Support" and so forth, and lastly, by its about New Zealand new latest news feeds. Similar to this, portals can be classified by their government services, department types and life events(Criado \& Ramilo, 2003)

The Australian one-stop portal e-Government recognized the importance of an integrated approach to electronic service delivery. It offers more than 80 interactive services to the citizens, including the business sector, which is a convenient way of dealing with government. Three ways of access to information and services are offered through this portal, by service types, (paying bills, applying for a grant); by life events (moving house, having a baby, etc); and by location (government agency or department) (Reffat, 2003)

PMIS is more aligned to the cataloguing stage of the e-government development model, which enables citizens to access the government information. A non-transactional website allows citizens to easily find policies and regulations and information that relate to government activities. Whereas the proposed Citizen Internet Portal wants to develop into the next transaction stage, where it allows citizens to complete the form and interact with government through an online presence. The transaction stage portal can deliver the public services through a web enabled interface and can assist the government to embrace citizencentric government. 
In terms of achieving e-government opportunities and advantages, both portals can do the following:

\begin{tabular}{|l|l|l|}
\hline E-government opportunities and advantages & PMIS & $\begin{array}{l}\text { Citizen Internet } \\
\text { Portal }\end{array}$ \\
\hline $\begin{array}{l}\text { Lower overall administrative costs to } \\
\text { government }\end{array}$ & Yes & Yes \\
\hline Provide more efficient government operations & Yes & Yes \\
\hline $\begin{array}{l}\text { Create a stronger and closer relationship } \\
\text { between citizens and government }\end{array}$ & Yes & Yes \\
\hline $\begin{array}{l}\text { Provide easier access to government for all } \\
\text { Improve the level of service to citizen }\end{array}$ & No & Yes \\
\hline $\begin{array}{l}\text { Allow greater access to decision-making } \\
\text { Empowerment of citizens }\end{array}$ & No & Yes \\
\hline $\begin{array}{l}\text { Provide more transparency in government } \\
\text { with more responsibility }\end{array}$ & Yes & Yes \\
\hline
\end{tabular}

Figure 6. Comparison of e-portals

Both portals can achieve lowering the overall administrative costs, such as PMIS enabling the connecting of separate agencies through a local area network connection which is in turn decreasing the exchange of large amounts of paperwork, while the information and knowledge sharing will be much more flexible. The Citizen Internet Portal on other hand wants to enable common standards and templates for agencies, which can create web-based front-end applications and services. The front end will accept users' data entry and the submission of applications from users. This creation will also help the portal to decrease the overall administrative cost, improving efficient government operation. (Government Document, 2011) 
Two examples illustrate the potential benefits of e-government services:

Every day, dozens of citizens stand in a line outside of the State Social Insurance General Office Mongolia. Insurance officials check that the paperwork for pregnancy allowances is in order. The process is vital for officials to not make mistakes on the amount of money paid and to match the pregnant ladies with their citizenship documents and all other necessary identification confirmation. The current inefficient manual procedure includes, first the lady having to get the information from the district hospital and then to register for the district pregnancy examination center; from there she has to take the approval letter confirming that she is registered for a pregnancy examination; then she has to go to a bank and open up a new account for payment of a pregnancy allowance; then she has to attend several educational classes on pregnancy. After all these physical process, the lady finally reaches the point where she can get paid the allowances. Such a complex and inefficient process is a burden for any citizen, but especially for an expectant mother. Especially in a country where half of the population lives in one city, and traffic congestion is a huge problem, where it can take several hours to reach each destination. All together this complex procedure takes the pregnant lady from one to two months of work to complete, until finally the allowance will be paid into her bank account.

Starting a business in Mongolia is a difficult procedure to go through for outsiders and even for locals. On the necessary procedures required for a businesses to open a new operation in Mongolia, it has been noted on the IFC and World Bank website (2011) that companies need to take following steps: At first, the uniqueness of the proposed company name has to be checked by the State Registration Department of the Tax Authority; second, the company must deposit capital in a temporary account, obtain a proof and pay the registration fee; third, notarize the statutes and charters of the company, notarize the schedule showing the equity share held by each partner; fourth, register at the State Registration Office, under the General Department of State Taxation; fifth, register at the local Tax Office; sixth, apply for social security with the Social Insurance Department; and finally, seventh, make a seal. (International Finance Corporation and the World Bank, 2011). Seven steps together can take thirteen days. All together it is a burden for businesses to follow all these steps in Mongolia and may discourage investment. An advanced e-government solution and supporting ICT could help significantly reduce the necessary steps, the need to visit multiple agencies in person and especially the waiting times between the steps. Facilities such as an online 
registration website can accelerate the process, enabling transactions over the internet, and make it easier doing business in Mongolia. The necessary government web pages all together exist under one portal where it makes the process even more understandable and easier to follow the procedures. This is the logic behind providing more efficient government operations. The current portal allows for providing information on time, which decreases the time needed for the citizen to search for the information, and a local intranet connection allows public servants to share all necessary information interchangeably. For the prospective portal, it allows to process the necessary application and forms through the internet, which brings yet more efficient operation of the government.

The current portal is not providing government services online but concentrates on information dissemination for the citizen, which can improve the level of transparency and increase citizen and government information sharing opportunities. It also allows citizens to communicate with government through e-mail and by using the "comment" section of portal, but it still does not make them empowered through influencing the decision making process of the government.

\subsubsection{Information System Success}

Since information systems became a main concern for any government and business, their successful implementation and their alignment with strategy also became key concerns. Evaluating the success factors of information communication technology in government is complex and problematic. Various kinds of studies have been done to demonstrate the success characteristics of the information systems. A better understanding of the success models will assist governments to gain benefit from e-government uptake.

One of the popular IS success models is the IS success model of Delone and McLean (1992) which demonstrates that this comprehensive IS success taxonomy posits six major dimensions (System Quality, Information Quality, Use, User Satisfaction, individual Impact and Organizational Impact) which can be interrelated and interdependent. 


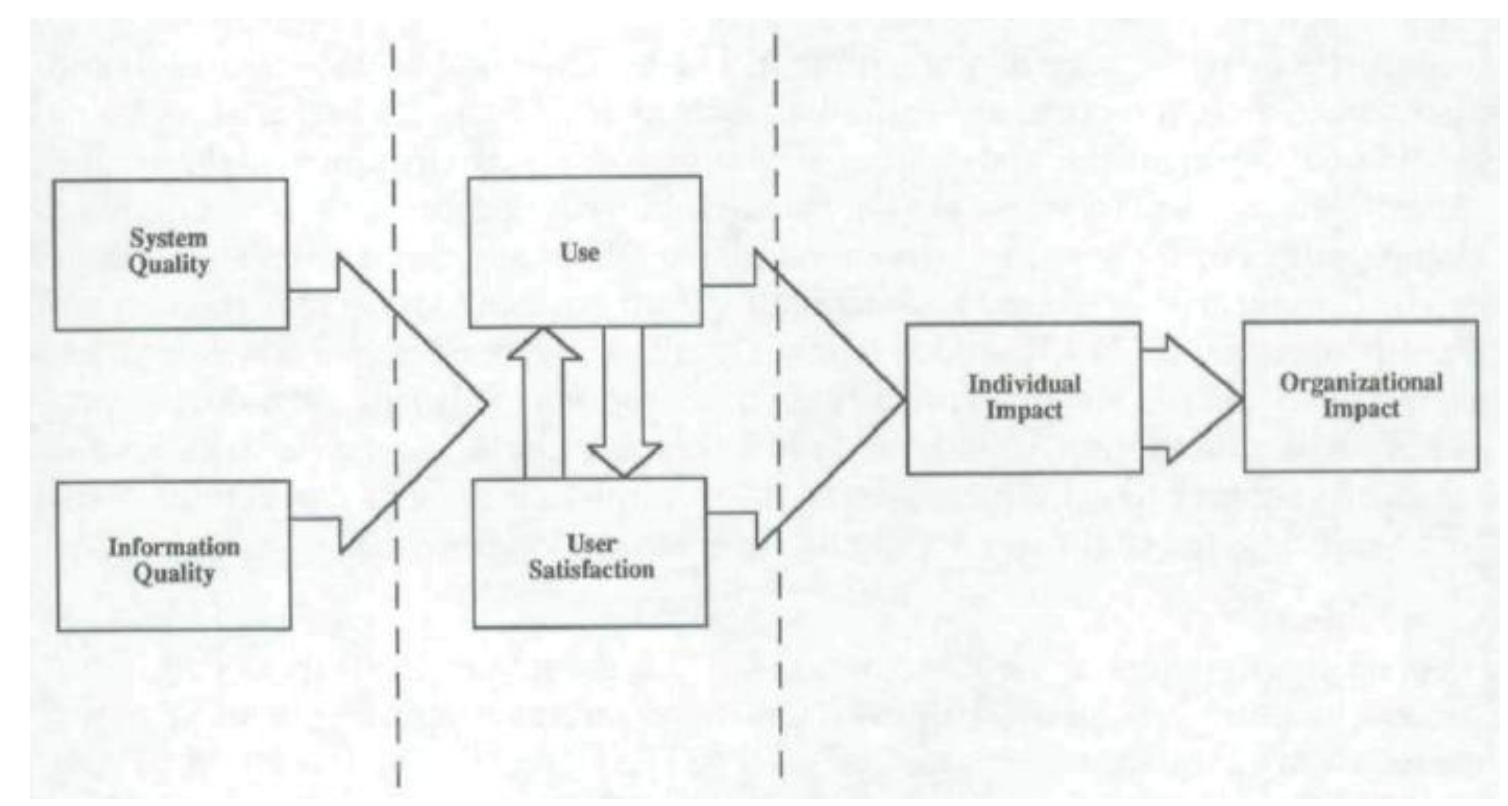

Figure 7. Delone \& McLean (1992), IS Success Model.

System quality: Research has suggested that the processing system performance itself is one of attributes to evaluate IS success, such as the efficiency of the hardware, its reliability, online response time, the ease of terminal use and so on. This success factor refers to the system performance from technical and design perspectives, such as the system always does what it should, whether it includes necessary features and whether functions often need correction or intervention.

Information quality: The information quality of a computer system is presented as a success dimension, including information accuracy, output timeliness, uniqueness, clarity and readability and so forth. The Delone and McLean study reviewed a total of 180 articles to achieve this comprehensive taxonomy. For example, an information quality category consists of more than thirty-three descriptions of measure, originated from nine different scholars' articles. Output of the information can be measured through its importance, availability, usability, understandability, and format as well.

Information use: This IS success factor refers to the actual use of the information system, which is typically voluntary, and can be measured by the time of use, usage pattern, number of accesses and dependency. (Delone \& McLean, 2003)_The success factor supports the idea that the intention of the system use is of significance. Also, the quality of use and intensity of 
use will also impact on the anticipated benefits of the system realization. The importance of the system and its continuity is based on decision makers' management judgments and it is wholly voluntary.

User satisfaction: This success factor refers to all users' interactions with a system and their perception of its value as a tool. Managers' system satisfaction ratings and user attitudes towards the information system's usefulness in performing their job roles are some of key attributes of user satisfaction.

Individual impact: An, information system can influence peoples' decision making process and the impact can be seen if it has '...improved his or her decision making productivity, has produced a change in user activity, or has changed the decision maker's perception of the importance or usefulness of the information system.' (DeLone \& McLean, 1992, p. 69) Therefore the impact on individuals, as well as its influence on their decision making process and organizational performance should be measured here by diverse attributes of success like decision quality, computer awareness, cost awareness, improved personal productivity, and quality of career plans. This success factor also refers to the quality of work environment and job performance. (Delone \& McLean, 2003) It may also be measured by how citizens may have learned through the presence of the portal and how it enhances their productivity (Gable et al., 2008)

Organizational impact: The last dependant variable relies on measures that relate to an impact on organizational performance and corporate outcomes such as total sales, return on investment. Whereas more advanced research has tried to identify intangible benefits, more measurable improvements such as in the areas of innovation, product quality, and marketing achievements are more often the main measures of organizational impact. This success factor gives the organization better and improved services and results. It can be measured through whether the system brought better performance for the organization, increased the productivity and process effectiveness, reduced the cost and time, increased capacity to manage a growing volume of activity, and improved the outcome overall. (Gable et al, 2008) Positive organizational impact, which is also called a net benefit, comes as a result of continued intention of use and subsequent user satisfaction. 
Delone and McLean (2003) also published a ten year update of their first research, developing and expanding on their original concepts

Most of the research articles are based on this Delone and McLean model of IS success, however, there are some other academic researches that explore IS success. Ballantine et al, (1996), designed their own IS model which attempted to improve the understanding of the concept of IS success by separating success into three fundamental dimensions or levels; 'the technical development level, the deployment to the user, and the delivery of business benefits.' (Ballantine et al., 1996). Each level has its own success factors which can be influenced by several exogenous factors.

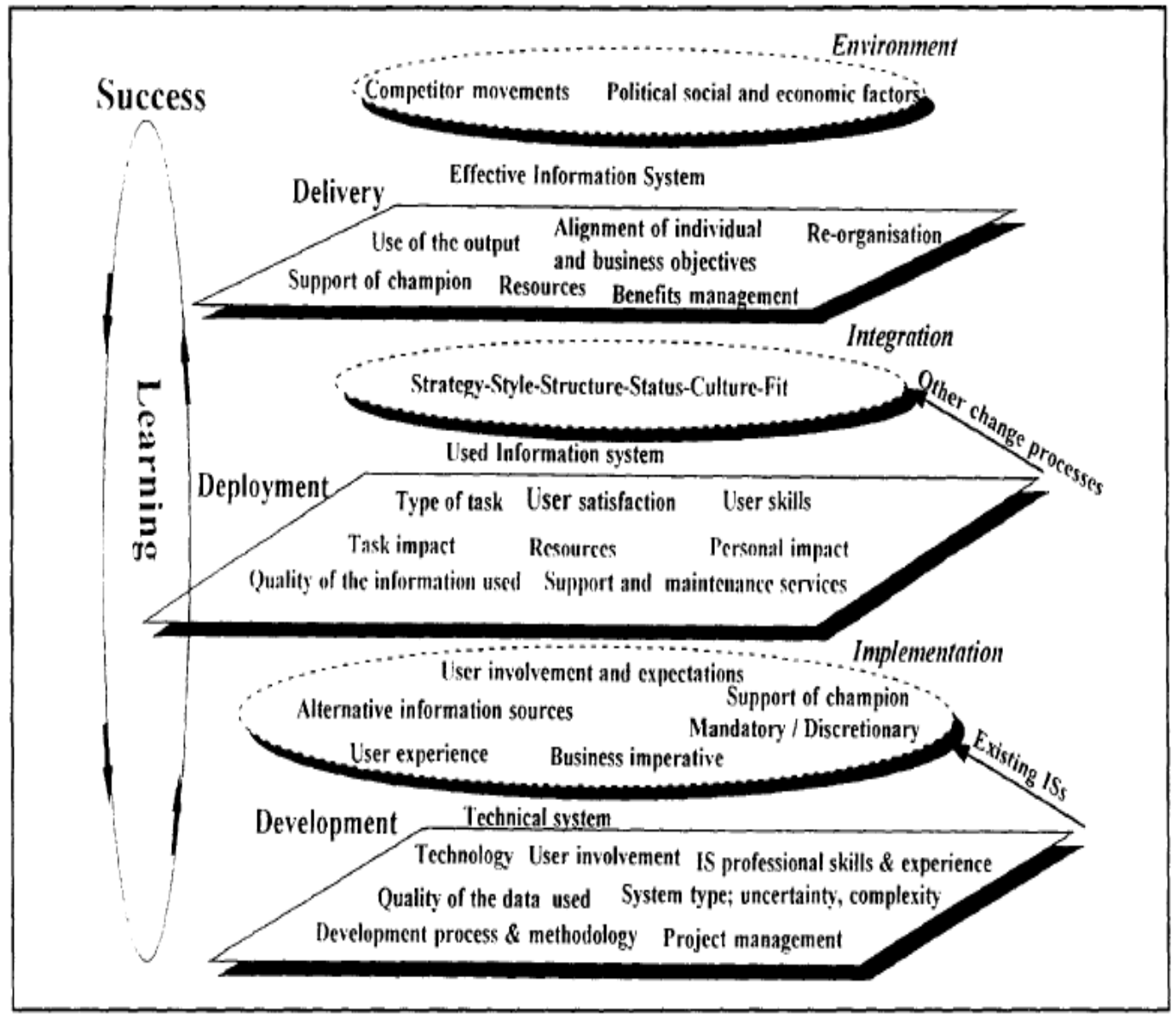

Figure 8. The 3-D Model Expanded

For example, from the development level to the deployment level a system can be affected by user involvement and expectation, support of a champion, political and social context, users' skills, the technology solution, and IS project alignment with business strategy. Some of the 
factors were the same as with the Delone \& McLean success factors, such as the quality of the information or data used, user satisfaction, and use of output, so these previously identified factors have been eliminated from the further investigation of the additional or unique factors.

So, some of the success factors from the model have been identified as an essential whereas other scholars also supported the importance of these factors. In addition to the success factors of the Delone \& McLean (1992) model, these unique additional factors were adopted in the data collection questions.

Some possible success factors identified by Ballantine et al., (1996) have been supported by other e-government and IS scholars as important and include:

\begin{tabular}{|l|l|}
\hline Success factors & Authors \\
\hline Support of Champion & $\begin{array}{l}\text { (Ballantine, et al., 1996; Benbasat \& Zmud, 2003; } \\
\text { Prybutok, Zhang, \& Ryan, 2008); (Elnaghi, } \\
\text { Alshawi, \& Missi, 2007), King \& Teo, (1996) }\end{array}$ \\
\hline Users' skills & $\begin{array}{l}\text { (Ballantine, et al., 1996) ; (Ndou, 2004) (Reffat, } \\
\text { 2003); (Gupta \& Jana, 2003); (Heeks, 2005) }\end{array}$ \\
\hline Political factor & $\begin{array}{l}\text { (Gil-García \& Pardo, 2005); (Ballantine, et al., } \\
1996)\end{array}$ \\
\hline $\begin{array}{l}\text { Project alignment with strategic } \\
\text { goals }\end{array}$ & $\begin{array}{l}\text { (Ballantine, et al., 1996); (Cegielski, Reithel, \& } \\
\text { Rebman, 2005); (Iribarren et al., 2008) }\end{array}$ \\
\hline
\end{tabular}

Figure 9. Success Factors and Identifying Researchers

Champion support. Ballantine et al., (1996) identify how a low quality technical system still can be successful with help of champion's support. Once the system is delivered, IS begins to deliver the business objectives. A champion's active support helps in this stage as well. Champion's support also has been proposed by Prybutok, Zhang \& Ryan, (2008) where they evaluated leadership, IT quality and net benefit in an e-government environment. They found the positive leadership outcome has an impact of positive IT quality. 
Users' skills. The skill of users also can influence the acceptance of an information system. Reffat (2003) says that technical skills will be required for implementing the e-government solutions, and also for using them depending on projects. All the way through development of e-government projects, e-government solutions change the work and the users' environment; therefore users attempt to learn computer skills instead of doing business in traditional way. (Gupta \& Jana, 2003).

People's skills and capabilities are one of the largest success factors of an egovernment initiative. Thus, training and education actions must be considered as a priority for handling the new process and activities.(Ndou, 2004)

Political influence Understanding benefits of technological solutions helps government to overcome the challenges and barriers. Beside this technological complexity, the political factor has been identified as one of the critical success factor by Gil Garcia \& Pardo (2005).

Project alignment with strategic goals The research study of Cegielski, Reithel \& Rebman (2005) found that IT strategies need to be aligned with overall organizational and business current and future goals. Business and technological alignment are the main considerations here, where emerging technologies support the overall organizational objectives, whereas technical alignment issues focus more on hardware, software and networks and how these will integrate with existing systems. Generally the government information technology projects should be aligned with the government organization's vision, its business strategy and priorities, at the same time aligning with national e-government strategies.(Iribarren, et al., 2008)

According to both the e-Government and a more general IS success factor literature review, measurement of the success of e-government initiatives might be most accurately achieved from considering the net benefit or organizational impact. For example, internet-based activity including an online presence, cost savings and access can deliver a net benefit or organizational impact as suggested by Delone and McLean. Their IS success model suggests the inter-relationship between these dependant variables, such as higher system quality and information quality impacting on the higher information use and user satisfaction, while positive user satisfaction and use leads to a positive individual impact, resulting in 
organizaitonal productivity improvement. (Delone \& McLean, 2003). All these dependant variables' positive performance will in turn deliver positive value for the government as illustrated in the earlier table.

However, the study is not examining the positive and negative relationship of the dependant variable, but has tried to realize through this literature analysis that a positive, multi-faceted improved system performance overall will result in productivity improvement and better positioning for the e-government. 


\section{Section 3. Research Methodology}

In this section, the research methodology is discussed, explaining why the researcher decided to follow the qualitative tradition. It then continues to describe the data collection and data analysis procedures and how the interviews were analysed by the researcher.

\subsection{Research Method}

The study intended to illustrate the important success factors of the successful e-government portal in Mongolia. A qualitative tradition has been adopted in the research, which is intended to examine the current PMIS portal's success factors.

Different kinds of approaches have been investigated to illustrate this research study, and the most suitable and comfortable approach was positivist.

In qualitative research usually the following three assumptions go together: positivist (Yin, 1994), interpretive (Walsham, 1993), and critical (Carr \& Kemmis, 1986) philosophical perspective of epistemology. The paradigm of Qualitative social research has been categorised by Chua (1986) and figure1 represents the underlying philosophical assumptions. (Myers \& Avison, 2002).

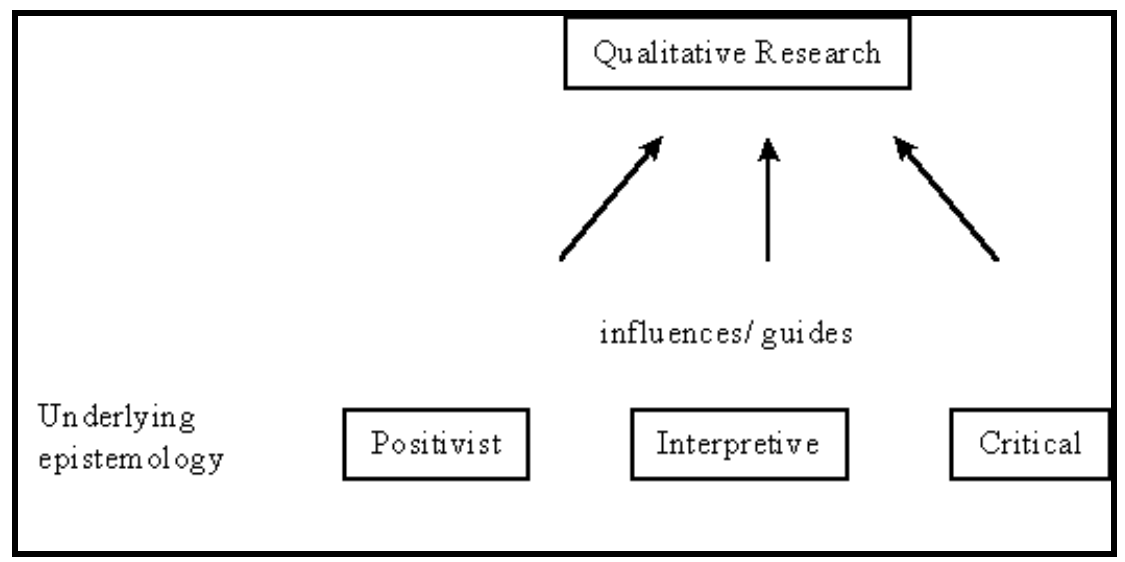

Figure 10. Underlying Philosophical Assumptions (Myers \& Avison, 2002) 
Further investigation has been done to illustrate what approach would relate users' experience of portal development with an actual existing model, through these three phenomena: underlying epistemological assumptions. "Positivist aim to forecast the general patterns of human activity regardless of historical or cultural context"(Burke, 2007). Positivist studies are premised on the existence of a priori fixed relationships within phenomena, which are typically investigated with structured instrumentation. Such studies serve primarily to test theory, in an attempt to increase predictive understanding of phenomena (Orlikowski \& Baroudi, 1991). Therefore, the research was conducted using the positivist approach that would assist the researcher to explore the experience of Mongolian government officials to express their opinions and thoughts on development of an e-government portal based on their knowledge and practice.

\subsection{Sample Selection}

The interview involved participants from a group of public officials who used to work on the e-government portal and e-government projects, including the proposed e-government portal. From the literature review, the researcher found that the Information Technology Department Cabinet Office of Government of Mongolia is responsible for administering the PMIS portal site. Meanwhile, the Information Communication Technology and Post Authority (ICTPA) is responsible for dealing with the overall e-government project throughout the nation.

Secondly, the authority was responsible for implementing the proposed Citizen Internet Portal and several people who work there were also involved in the PMIS portal development.

Therefore, a selection of participants form both sides was helpful. These people had experience and knowledge about portal sites, and what kinds of factors influenced the success of an e-government portal web page.

The researcher contacted interviewees from both organizations through voice over internet calls. One person from Information Technology Department Cabinet Office of Government of Mongolia was contacted, who acts as an expert on PMIS and is responsible for administering the current portal. Three people from the Information Communication Technology and Post Authority participated. One of them acted as a member of the technical 
group of the PMIS project during the project's implementation, when the Ministry of Infrastructure and Technology Department Cabinet Office of Government of Mongolia were cooperating with UNDP.

One interviewee is the e-government expert in the country, and acts as a manager for the World Bank funded e-government Citizen Internet Portal project in ICTPA and also acts as a working group member in the government which deals with all e-government activities in the county including PMIS operation. The other participant is a deputy chairman of the ICTPA which is responsible for managing and coordinating all e-government related projects and regulations in the country.

Also one independent participant from USAID who had a project involvement in an egovernment portal has been interviewed.

Four of the respondents from the government had served the government for six years or more, the remaining individual had served with an international agency for more than nine years. The information systems used by the government were justified by these experienced people.

\subsection{Data Collection}

The research was conducted using a semi-structured interview technique for its data gathering, along with open ended questions. Interviews are the most often used technique for gathering historical data from the memories of interviewees. (Seaman, 1999)

A basic set of twenty-four questions were asked using voice over internet. Interviewees were free to answer the questions without any limitations, while the researcher was able to bring up new questions during the interview, which helped to explore more about the topic and to investigate unforeseen information from the answers given. Also, open ended questions allowed the exploration of a more meaningful answer from the knowledge of the interviewee. Prepared questions assisted the researcher to focus and direct the interview while leaving scope for flexibility. The interviews started with a short explanation of the research studies. 
Things considered during interview adaptation (Fontana \& Frey, 1994):

- Accessing the setting. In order to conduct the survey the researcher used Skype and Yahoo messenger tools to carry out interviews.

- Understanding the language and culture of the respondents. Interviews took place using both English and Mongolian. Some participants had adequate fluency in English to choose to take the interview in that language, making it easier to interpret and analyse the data. Two participants' interviews were translated from Mongolian to English. Secondly, the research introduction sheet was provided prior to the interviews to make participants aware of the research questions and topics. The researcher did not have the difficulty of any cultural or social differences or barriers during the course of the interview.

The researcher presented herself as a representative and a student of Victoria University of Wellington. Presentation as a learner and researcher made the interviewees more comfortable and did not raise any misunderstanding or confusion during the interview.

\subsection{Data Analysis Procedures}

The output of the data collection phase was audio files of interviews. The analysis has been based on the coding schema which identified success factors impacting on the existing portal system. The data had been coded according to their pattern and trends which assisted the researcher to organize and break up the data. Some of the coding has been identified through IS impact measures that have been identified in the study.

The result of the data analysis showed that some of the data were supporting factors of the Delone \& McLean (2001) model, 3D model of Ballentine et al., (1996). Several potential challenges were identified during this phase and they have been introduced in the following sections of the study. 


\section{Section 4. Data Analysis}

The researcher identified the following ten significant factors which emerged from the interviews, the table representing their attribution by each respondent:

\begin{tabular}{|l|l|c|c|c|c|c|}
\hline № & Success factors & P1 & P2 & P3 & P4 & P5 \\
\hline $\mathbf{1 .}$ & System quality & Yes & Yes & No & No & Yes \\
\hline $\mathbf{2 .}$ & Information quality & Yes & Yes & Yes & Yes & Yes \\
\hline $\mathbf{3 .}$ & Information use & Yes & Yes & - & Yes & Yes \\
\hline $\mathbf{4}$ & User satisfaction & Yes & Yes & - & Yes & Yes \\
\hline $\mathbf{5}$ & Individual impact & - & Yes & - & Yes & Yes \\
\hline 6. & Organizational impact & Yes & Yes & Yes & Yes & Yes \\
\hline $\mathbf{7 .}$ & Champion support & Yes & Yes & Yes & No & Yes \\
\hline $\mathbf{8 .}$ & User's skill & Yes & Yes & Yes & Yes & Yes \\
\hline 9. & Political factor & No & No & - & No & Yes \\
\hline 10. & Project alignment with & Yes & Yes & No & No & Yes \\
& strategic goals & & & & & \\
\hline
\end{tabular}

Figure 11. Significant Factors Identified by Interviewees

\subsection{Interview Findings}

Each of the ten factors is described and challenges associated with them are discussed, with interviewee comments used to illustrate the issues:

\section{System Quality:}

System quality can be measured through its design, the performance of the system, whether it includes necessary features and functions, and always does what it should. (Gable et al., 2008). It also addresses questions like if it is hard to access to this system and does it often need correction? 
Data analysis supports the importance of system quality in a government portal, specifically the need to be upgraded constantly due to constant and continuing changes and innovations in technology solutions. The government of Mongolia tends to use and adopt the best and already tested solutions in the market rather than writing it themselves, this makes them easier to deliver the good system performance.

"We already use best cases in the market - that is why it does not really affect the performance of the system."

\section{Challenge:}

However, rapid change in technology is creating specific needs from the egovernment portal to adopt certain features and functions due to public demand, such as social networking sites, Facebook and Twitter, which can give the users possibilities of constant communicating with government.

\footnotetext{
"We need some change. For example, Facebook, Twitter and new technologies are affecting social and political life of Mongolia. In my view, we need to use those technologies which are already in the market and use in portal to make it more attractive and provide more transparency."
}

However, in terms of looking at the infrastructure, the impact was huge for those using the system. From the time of the system launch until up to only a few years ago, the country had limited connectivity and poor infrastructure. These limitations and a digital divide made the system perform and operate according to their constraints. This situation needed real actions towards improving broadband penetration and other connectivity related activities and policies.

"The network was a very important aspect because internet speed was very slow and people used to connect through dial-up connection which is very slow, and secondly there were not any high speed broadband connections, therefore the government website design and functionality needed to match 
with this internet connection, so it makes it a lot easier for users to download the information and contents."

All participants agreed on the system needing improvement, such as more on a way to achieve a transaction stage which can support delivery of e-government services. They say that the system should include e-service delivery features and more interaction functions. However, the possibility of the current portal for further growth is quite unfeasible in terms of a lack of its backend system integration, in which all government agencies' systems exist separately. Therefore even if the national portal wants to deliver e-government public services through its system, it lacks the potential because of the supporting infrastructure inability.

"Technical specification is very important for any e-government portal and website project because technology is the fastest industry where rapid technology development is enabling their customers to upgrade their current version to a newer one. For example, when the Mongolian government was implementing the e-Government portal project there was limited technology availability in certain aspect such as internet speed. People were using very slow dial-up connections, and e-government portals' specifications have been designed specifically for this purpose, making it easier for users to download and upload the content and figures. When a country reaches a certain level in its development, and the availability of technology is abundant, then people's level of requirement increases as well, where they have high speed broadband or mobile communications everywhere and want to get flexible and adjustable content and information figures from the e-government portal. In those circumstances, the government needs to continuously and constantly upgrade and adjust its capability in time with technology changes."

Overall, system quality is important in terms of including the necessary features and functions, to do what it is supposed to do; the government portal is doing what it supposed to do. 
"I think we are doing the best that we are able to do now. It's my personal judgment on that."

The government feels comfortable with its system performance because they have chosen already tested and the proven best models in the market. However, in this case the government needs to be aware of the system functionality and flexibility which prepares the system for future upgrading and improvements; otherwise there is a risk that user interest and usage will decline unless features and content are kept fresh

\section{Information quality}

Information quality has been identified as a success factor of the current egovernment portal of Mongolia. As specified in the IS success factors sections of the study that the information quality is measured through information usability, format, accuracy and so forth.

All interview respondents agreed that information quality plays an important role for the system's success. Information quality has been considered as an important issue of the portal at the initial stages of the portal development, but after several years of existence the quality has been gradually allowed to diminish from their main focus. The portal was the first and initial e-government directed webpage in the country which is why the portal was able to provide timely and usable information at that time.

"In the beginning, the project information unit was giving greater attention to the quality of data. They introduced some procedures for updating news in PMIS. But, when they completed the project, they no longer cared about the quality of data. Nowadays quality of data is very important"

Users' experience was towards using electronic equipment and getting information through online was considered a very low priority at the same time. Therefore their need of information importance, usability and format was fulfilled through the system. 


\section{Challenge:}

However, due to the dramatic development of ICT in the country in recent years, and improved users' skills and experience of technology, it was not accustomed to this portal which required more information and service consistently. Therefore in some ways the system is declining in its ability to provide information that is usable for people.

"When a country reaches a certain level of its development, and availability of technology is abundant then people's level of requirement increases as well where they have high speed broadband or mobile communications everywhere and want to get flexible and adjustable content and information figures from the e-government portal"

Secondly, there are no specific guidelines or portal usage documents that direct accurateness and format of information that is distributed through each of the government agencies' webpages, as well as through the portal.

"So this PMIS does not have these exchange standards which help data to move from one place to another without changing and disturbing the quality of data."

Therefore, the administrator is not able to affirm whether information is being distributed through the portal is actually accurate or not.

"Therefore information that shows on the page depends on that specific agencies' own web information, so the information quality is not checked by PMIS. PMIS only confirm whether that specific organizations' name is correct or not."

However, overall the participants agreed that information quality is the most important factor needing to be considered. 


\title{
3. Information Use
}

The third measure is actual information use, which can be measured by the amount of user connection time, actual charges of computer use, frequency of intended use which is typically voluntary, and can be measured by usage pattern, and dependency. (Delone \& McLean, 2003). The success factor supports the idea of the intention of the system uses and use by whom. Also the quality of the use and intensity of the use also will have an impact on the anticipated benefits of the system realization. Importance of the system and its continuity is based on decision makers' management judgments and it is wholly voluntary. From an e-government perspective, it is important to identify different user communities, for example, the public, government departments, private entities and organizations, and to measure their usage as well as total aggregate usage

The actual level of use of the system is quite high in the country. It gets as many as 1000 hits a day. The system is used by the general public and by government agencies themselves. The main usage of the system is normally for information gathering, for example getting contacts of government departments.

\begin{abstract}
"The performance of the portal is a quite high and its one of the main page that Mongolians visit every day. You can see the visiting numbers are always increasing and one of the very crowded website actually."
\end{abstract}

\section{Challenge:}

As mentioned earlier, the users' expectations got higher; however, actual use of the system is not going beyond just information dissemination stage. Therefore, the government perceives this increasing demand of the public and is attempting to move into a more transactional portal and a more interactive website which integrates government departments.

"Portal provides general and basic government information. Users can access to government websites through this portal. Not interactive and cannot download the forms and applications but it's called one entrance point for the users to find the government websites. You cannot directly 
find the needed information from the portal. its not meeting users expectation now. “

The intended use of the system is decreasing slowly, which makes sense because of the limited features and possibilities of the system. The participants say that the system is working in this its highest capability and possibility where we cannot move beyond this level. This level refers to just dissemination of government information. If we want to move more beyond this level, such as the ability to download forms and make a transaction through the portal, and to interact with the public through the portal, the government is required to integrate all the government systems that are operating individually such as taxation and customs systems.

"Government information system is integrated at all. For example, tax system customs system and national citizen registration system, all work separately. Integrated information system is not built yet which should support portal to deliver its main functions and goals through one window."

\section{User Satisfaction}

The system meeting the needs of the public and satisfying them is one of the realistic factors of measuring system success. However, the government portal of Mongolia did not measure any user satisfaction attribute. When the system first launched in 1997, the Information and Communications Technology for Sustainable Human Development project of UNDP undertook a user satisfaction evaluation study in 2000 and published a report. At that time, users' satisfaction towards system has been measured through case study at several agencies from a users' perspective. (Davaakhuu \& Delgermaa, 2000) The study tried to find what barriers and shortcomings users are facing in terms of using the new PMIS (Public management information system). Since then, no specific user satisfaction measurement had been taken up until 2009. In 2009, the Information Communication Technology and Post Authority hired international consulting for evaluating users' satisfaction with the current portal as a part of the foundation of the future Citizen Internet Portal. 
"Last year we had this survey from citizens. We put some polling modules into our portals and we tried to get the response from the users whether they can get the information. We measured in three levels such as good average normal and bad. This survey got response from around 1000 people and result was average good. Citizens of Mongolians were quite satisfied with the portal."

So, a user satisfaction index showed quite a good result regardless of the above illustrated challenges, but constant user satisfaction measurements need to be taken for precise attributes.

\section{Individual Impact}

Measures that show how the system assisted individuals to learn more, how it improved awareness of ICT for the user are overall indicators of the individual impact at work. Perception of system usefulness and importance are of great significance to the government, which can take advantage of the ICT adoption. Through use of the system, individuals (government IT professionals and general users such as businesses and citizens) learnt how to interact with new technologies, how they can benefit from using the system. This adoption process brought a big impact for these users, such as IT professionals enabling them to process their work more efficiently.

"Government officials did not know how to update their websites.

However, this situation has changed now dramatically. Understanding the importance of the website developed to the next level where they started to initiate own new ideas about how to upgrade and improve the website."

Due to the constant training, the individuals' impacts were increasing where they can operate on new applications and email system.

"The PMIS project also enabled government agencies to exchange email, starting to use office applications, therefore in that respect the project was very helpful for the public servants to learn the new technologies at that 
time. They had several barriers to use the system such as the language barrier, technical skills, little training, slow connection and so forth, but overall it was a new experience for them even if technology solutions were basic and simple."

Citizens have been assisted to navigate through government websites and information which helped them to save time and money.

"The general public got quite used to using the PMIS to connect the those government departments websites, which is easier to remember the one website name rather than knowing domain names of each individual government department's website."

\section{Organizational Impact}

Participants discussed various impacts and values of the system. They believe that the system brought a huge impact to support government by increasing the productivity of the staff, increasing transparency within the government and saving time of users, even though it was difficult for the system to operate in a time where the country needed to take a first step towards delivering government information online. A very limited number of government websites used to exist at that time, thus its impact on increased awareness of departments for improving design and building websites were significant, and the single system enabled them to expose and share their information and news through one single point of access for public.

The government agencies started to build their own websites and do constant updates on content and information. This encouragement and support of government agencies gave reward back to a society where citizens were enabled to access government information and contacts equally. This brought an impact for users to save time and enabled government transparency and openness.

One participant elaborated this:

"it's in an one place, people know who is doing what and that way government became more transparent." 
Transparency has often been a big concern for the government, which can improve trust and belief from the public. The government continues to struggle to improve the transparency and open government through the e-government goals.

In regards to saving time of users, two typical illustrations for participants are:

"Single webpage for the users save time, money and increase the transparency within the government."

And,

"General public quite used to use the website connecting to get into those departments rather than knowing domain names of each individual government department's website. “

\section{Champion's Support}

The system has been initiated under the government of Mongolia, so the project champion was the Prime Minister of Mongolia. His role for leading the project and giving the support for sustaining the continuity was critical. He used to give the direction to the cabinet secretary office to cooperate with the other government agencies and make a commitment for achieving the goals. In that way the portal success was highly influenced by a champion's commitment and his interest in the project outcome. His role was mainly supported by the Cabinet Secretary Office and exclusively represented by the Information Technology Department Cabinet Office of government of Mongolia. The secretariat office provides the champion role for all other government agencies to achieve common goals of the project.

For developing countries, a champion's understanding about ICT and supporting the initiatives are key issues for delivering successful e-government projects. One participant demonstrated the importance of his role and the overall champion function.

"Now project champion is prime minister so government leadership is very important, secretary general cabinet office takes the responsibility to handle the all government organizations work and its work flow and they support all the government departments main projects that's why that organization's 
leadership and their chairman's role is very important for the project outcome."

\section{User's Skill}

Ballentine et al (1996) affirm that the skill of users deployed for implementation will also influence the acceptance of the system. User skill is a very important factor for making a portal successful. The ICT literacy of users closely associated with ICT professionals for government agencies and general public in this study. The ICT professionals' skills are influential in terms of delivering the websites with fully functional and information-abundant websites in the portal. Secondly, operating them and managing websites requires knowledge and experience. During the project implementation phases, the project team took several training courses across the public departments.

This helped the website administrators to learn and be more confident to use the system.

\footnotetext{
"For example, we connected all the government agencies but people who were to work on that had limited skills, therefore we organized several training sessions in one of the university buildings in Ulaanbaatar."
}

ICT literacy and ICT professionals' skills through the portal had been dramatically improved. Well trained and educated professionals assisted the system performance in a proficient way.

However, the government has a high turnover of staff with a recognized difficulty in retaining well-educated and trained personnel. Because of this unstable staff situation the government faces a lack of human resource and professionals. Therefore, the system needs to be less dependent on the human resource skills in order to be successful. 
"A second barrier is pretty hard because sometimes people come and go in government organizations. When we train them most of the staff would leave after two to three years and we would have new people to train."

Beside the professionals' skills, the user skills also refer to the general public who are customary users of the system. Because of inadequate skills, the public users may face difficulties in accessing and understanding government information provided. The country has a sparse population which is settled all around the country in low density. Rural Internet users are less skilful than urban users, where infrastructure and information technology availabilities are less widespread.(Ulziikhutag \& Sukhbaatar, 2006)

"Users skills do effect use. Depending on the infrastructure availability, how it is in the city or how it is in rural areas has a real differences. There are places that do have limited internet connection or no connection. In the city case, users' skills are much higher than rural areas obviously",

But mobile devices are a more convenient and affordable technology for these people which brings big progress on users' skills on technology practice. The system is facing the challenge to consider changes which need design changes according to these new technologies. One participant mentioned:

"In the last 3-4 years we introduced mobile services in some level. Local people used to use the mobile phone for talking and sending SMS. Nowadays they are browsing websites by mobile phone in Mongolian and English. They want more public applications. They have the basic skills for using portable devices."

Thus, the government believes that private entities and any organizations which are dedicated to support the improvement of the public's ICT literacy and education will be encouraged and promoted continuously. 
"For citizens we need training and from the government we highly appreciate and support any entities that are supporting IT education of all people and users.”

\section{Political Factor}

E-Government uptake is surrounded by political issues. Because of the e-government project's nature, which engages with political support and money issues, this factor's importance has been discussed in many studies. However, participants in this research elaborated that in the initial stages of the e-Government system implementation there may be a connection with political support, although after a while it did not matter for the continued operation of the system.

"PMIS was a small part of the "Sustainable Human Development" project, as a whole this project needed huge political support from the government because the project was intended to enhance the whole government administration process under the "Management Development Program" of UNDP”.

"For just the PMIS case, I would say we do not have any effects from a social and political context, however in the sense that PMIS does include the other government websites behind it and access to those websites, it has some impact on organizations' leaders understanding, which maybe cannot be said to be an actual political effect. Maybe it can be just said leaders support was critical, except that not directly."

\section{Project Alignment With Strategic Goals}

The project needs to be aligned with overall country's e-government strategy and goals. 
When PMIS was first initiated, at that time the country had not formulated its egovernment strategy and goals. The "National e-Government Master Plan" had been formulated in 2005, and the "e-Mongolia" national ICT strategy had been formulated in 2005 as well. Currently the country is working on formulating an "E-Government National Program", which may give modifications for the current policy and regulations.

In this matter, it just followed the flow of the government general documents and guidelines. It can be said that PMIS is partially aligning with a few formal statements of these new formulized documents, even if it was established earlier than these documents.

\begin{abstract}
"General statements like "make government information available" and "make it easy to access for the public" have been documented in the e-Mongolia national program, e-government master plan and government action plans. In that sense, the PMIS is aligned with these goals."
\end{abstract}

On the other hand, the goals and strategy of the country have dramatically transformed since PMIS was established. A national e-government strategy and goals have become totally different to what they were in earlier years. In that matter, PMIS was not aligning with national strategy and goals, as it was not covered as a main project.

"Of course no, we already changed our strategy since the PMIS portal was established. For example this year we revised our strategy. So this means the last version of the strategy is six years old but not implemented yet. That's why key projects are prioritized and the e-government Citizen Internet Portal is one of them. 


\subsection{Additional Factors}

The study identified three main challenges which the system faced throughout the operation. These two main challenges are summarized by the researcher, to demonstrate what had emerged from the findings:

1. Legal and regulatory challenge

2. ICT infrastructure challenge

3. Continuity of the success factors

\section{Legal and regulatory challenge}

As mentioned in the prior information quality section, because of limited or no supporting legal and standardized environment for e-government projects, the system gives less qualified data and faces more difficulties on system expansion.

"Legal and regulatory factors. Currently we do not anhave e-government Act or any legal document that support e-government. We definitely need one regulation or at least law for e-government and to support those people who are using the e-government system. Without this we cannot take our leadership into e-government. “

Secondly, difficulties appear when trying to achieve and set the long term goals when a poor legal and regulatory supporting environment exists.

There are not any guidelines and policies that specifically deal with the e-government portal. There need to be a government intranet, along with the portal which disseminates information to outside. This plan is just under its project planning stage. So there are no specific goals and documents that refer to the e-government portal.

Digital rights and data privacy concerns raise issues when it comes to portal operation, such as the portal administrator was not aware who is responsible for what 
data and information. Information accuracy and accountability is apparently imperceptible in this matter.

"Also, we need a legal environment on information security, confidentiality which is not settled yet."

When developing countries, especially central governments, enter into a digital environment without any comprehensive legal regulations that would protect the online environment, there is a high level of risk. Data privacy, digital rights acts that ensure authenticity and integrity of digital content, online security, transactions acts are emerging areas in this context.

\section{Information Communication Technology Infrastructure Challenge}

The study found that sufficient information technology infrastructure is beneficial to successful system implementation. By setting in the actual infrastructure, the system has a better chance to deliver a successful outcome. In the development of the system, PMIS was not supported by an adequate infrastructure environment; great emphasis was placed on the development of national infrastructure by the government but still national broadband penetration was very small, internet speed was very low and hardware practice was very limited in terms of PMIS development. All these impacts negatively affect system success, which resulted in a system to be designed according to these limitations.

“ The network was a very important aspect because internet speed was very low and people used to connect through dial-up connection which is very slow and secondly there was not any high speed broadband therefore government website design and functionality needed to match with this internet connection so it makes it easier for users to download the information and contents."

The most visible indicators of these inadequate information technology infrastructure conditions can be illustrated by some of these following figures which demonstrate the difference between the 1990's and the beginning of 2004. Internet users' rate per 
100 were no more than two, personal computers' usage were no more than five per 100 inhabitants until 2004, and even fixed broadband internet penetration onlystarts in 2004 with sharp increase in 2009.

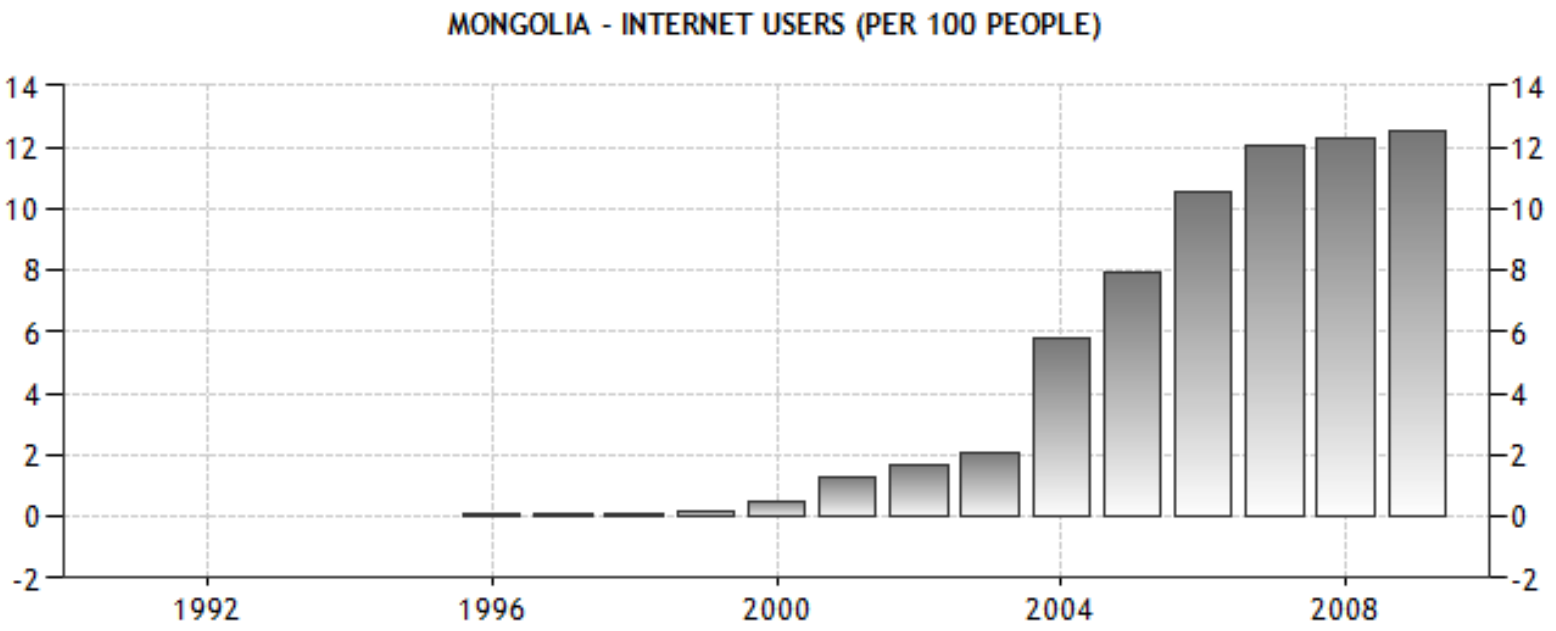

Figure 12. Mongolia - Internet Users (Source: Trading Economics)

MONGOLIA - PERSONAL COMPUTERS (PER 100 PEOPLE)

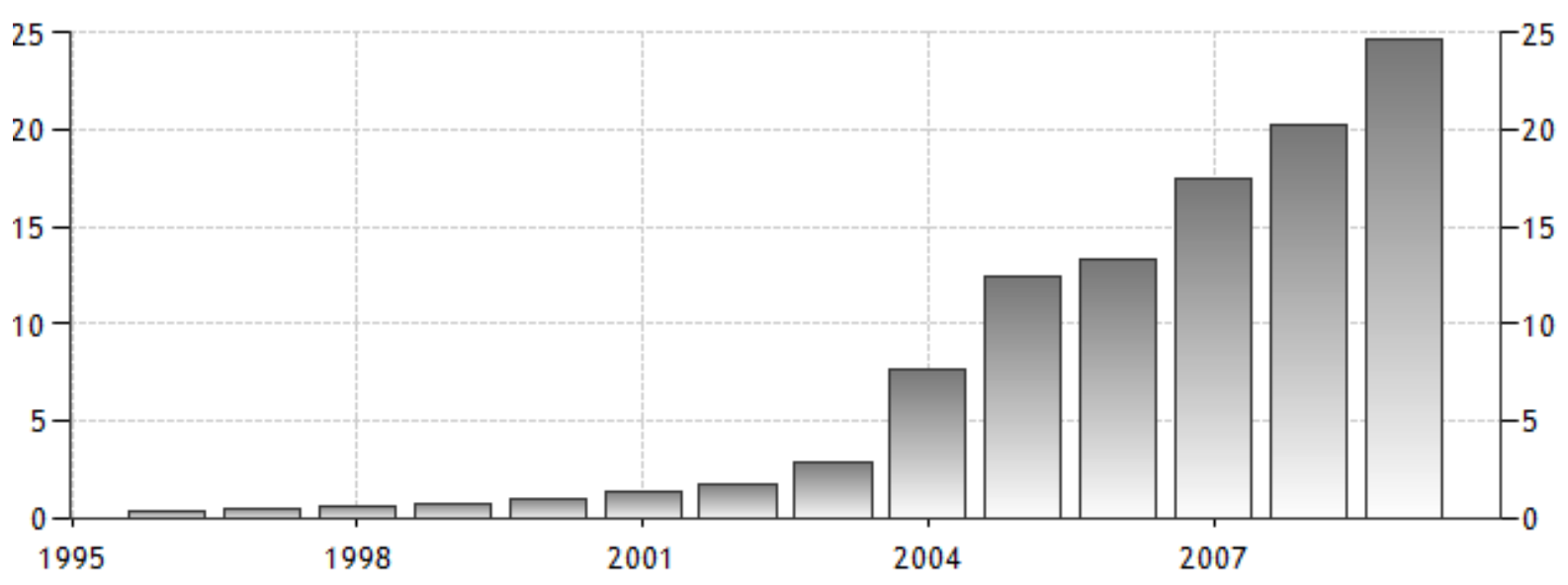

Figure 13. Mongolia - Personal Computer Use (Source: Trading Economics) 


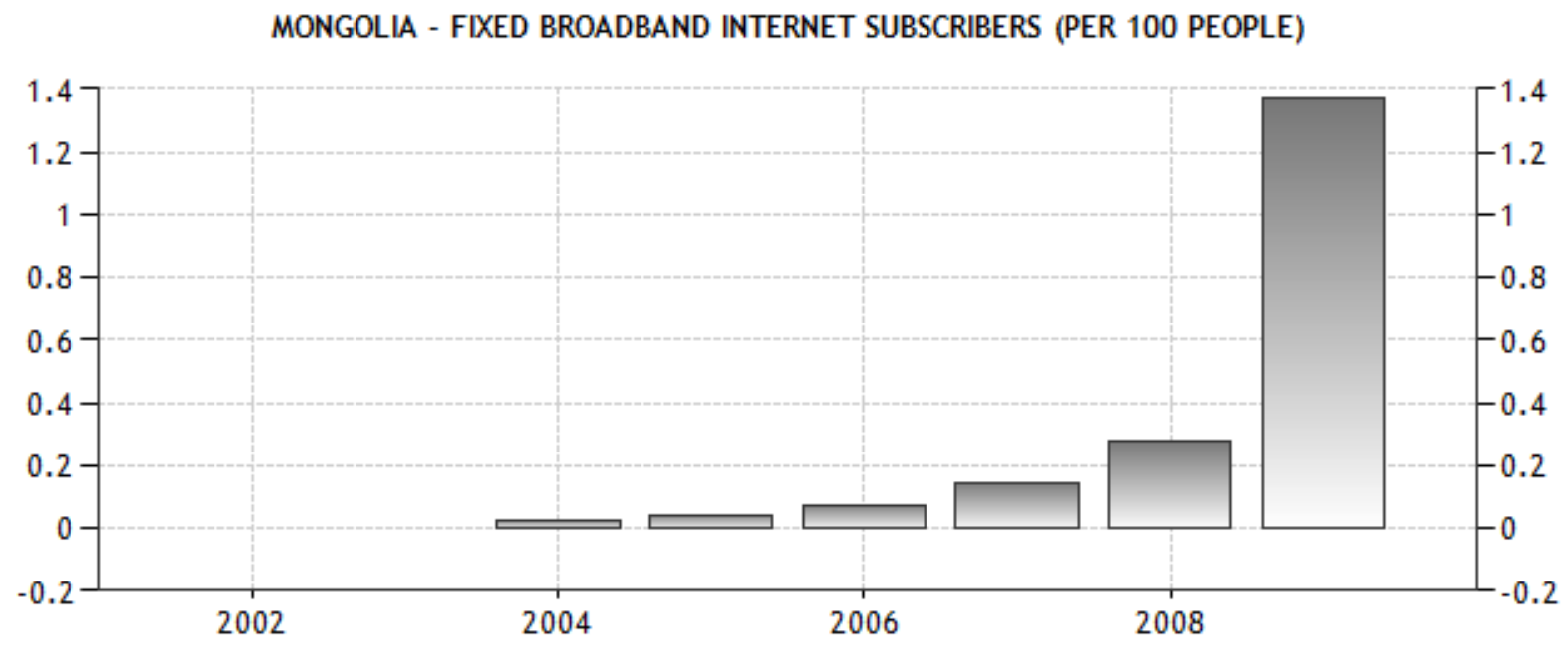

Figure 14. Mongolia-Broadband Internet (Source: Trading Economics)

A system would be valued if the users can get what they want from government through an affordable and flexible infrastructure choice. Therefore, the project and decision makers considered infrastructure availability from the perspective of an IT user. They deployed a plan to install an intranet connection and computer distribution along with the PMIS portal implementation.

"In addition, the project targeted to connect all ministries plus several agencies and governor offices through a local area network (LAN). Therefore, on one hand, it was the website which is supported content, on the other hand it was hardware deployment which included the network side. More than 1000 computers in all ministry offices had been connected to a LAN connection."

These conditions needed to be improved. Participants identified a need of further improvement on infrastructure availability, such as the government back end system integration which has been mentioned consistently to describe the supporting subsystems of government departments. As mentioned in earlier sections it includes systems such as taxation and customs systems integration. 
"My personal view is first we need to manage this back office system and legal support."

\section{Continuity of the Success Factors}

Continuity of the success factor was critical for maintaining all these factors in the egovernment initiative. It may have several reasons behind it, such as one participant mentioned that in government departments it is hard to retain the well educated and trained IT specialist.

" A second barrier is pretty hard because sometimes people come and go in government organizations. When we train them most of the staff would leave after two to three years and we would have new people so have to overcome such a barrier again."

After several years of work they just go somewhere else, the next person comes and again he or she takes time to familiarize with the system and once he or she gets settled for a while and again goes. This entire circus makes it difficult for government departments to maintain the quality of information and system on one hand. On the other hand, every four years due to government elections, government departments' administration gets changed. Maybe because they have less understanding of the work and the projects, new heads of the government departments may hesitate to continue the prior administration's work and projects. In that way, some e-government projects face difficulties of continuity.

"The most important step is for each government and even next government should support and continue to this project because every single government starts new project in a new way and then there would not be enough time for single government to do it. If government continue and support the previous government's projects if its successful and build up on will lead to the success. Then E-government will be even more successful with this strategy." 


\section{Section 5. Discussion}

A major contribution of the study was to enable a better understanding of IS success in an egovernment portal context. Its study highlights the importance of these success factors in producing a positive outcome from an e-government initiative. The e-government portal of Mongolia strongly supported the success factors of the Delone \& McLean model and the Ballantine 3D model. The study underscores the importance of information quality, system quality, system use, user satisfaction, organizational impact, champion support and users' skills, project alignment with strategic goals and political factors, all of which are used in this paper to examine the e-government initiative research. To deliver them successfully, the government needs to focus and needs to measure the quality of their operation.

- System quality: The study's findings suggest that system quality is as important as improving the overall performance of the e-government initiative, so that the government can achieve their mission of serving the public. System quality should be the primary focus of the e-government initiative, but the government of Mongolia may rely too much on off-shelf products, which have been interpreted as a consequence of their preference and intent to use well tested products and accepted best practice evidenced in overseas examples, which might have eliminated the possibilities of considering the individuality and uniqueness of the country's customs, which may have been better served by a more bespoke solution. Relevance of the system quality, which refers to the e-government system's efficiency of its hardware, reliability, ease of use and accessibility for users is also important. Therefore, identifying the right technology and ensuring sustainable performance of the system were critical.

- Information quality: Information quality showed that accuracy, format and usability are important to the e-government initiative. By focusing on each area, the organization should have strengthened its information quality, which is key to driving the success of the project. The result showed that information quality and its continuity need to be considered carefully in all system development phases, with interview responses showing considerable weakness in this area. The organization needs to make sure that information quality is meeting users' expectations all the time, because the knowledge and practice of users are constantly changing, which 
leads to an increase in the belief and expectation by the users of obtaining constant, integrated, standardized, usable and accurate information from the government.

- Information use: Information use was one of the measurements that showed the successful performance of the e-government initiative. Also identifying who is using the information was important. In the portal, the citizens of Mongolia and its government departments all were the users of the system. The usage rating of the system showed a good result initially, but intended use of the system is declining gradually as it has limited updates of system features and applications. People require a more advanced interactive and service-oriented portal system, whereby it allows a user to fill in the form and send it back to the government department and provide the facility to communicate online.

- User satisfaction: According to the study results, the user satisfaction rating was falling as well. User satisfaction determines the strength of the system and shows where it may need improvement. However, this e-government initiative did not take user satisfaction measurements regularly, resulting in an unsatisfactory set of measurements. However, the user satisfaction factor was identified by respondents as one of the critical factors of success e-government initiative.

- Individual impact: Participants' responses were in agreement with the literature on the individual impact the e-government portal has had, the way it has influenced the government officials' everyday activities and made improvements in interaction with information technology. They found that the system is useful and important in this respect.

- Organizational impact: Organizational impact had been a matter of concern, which is a more direct measure of the final success. Organizational impact was illustrated mostly in a positive way where it has impacted the openness of the government's activities, decreased the level of bureaucracy and has saved the time of users. Better performance and increased impact of the e-government initiative has actually assisted the overall country's e-government profile. 
- Champion's support: A champion's support facilitated the successful deployment of a strategic e-government portal in Mongolia. Understanding the ICT and its usefulness has to do with the champion's vision and ability. Support is required more when the country has a top-down decision making approach. Hence, the study indicated a substantial belief that the champion's support has had significant influence on the e-government initiative.

- Users' skill: The users' skill study findings completely support the literature review, identifying that both experts' and citizens' skills were critical to be able to operate the system in the longer term. The project supported various training and education programs for improving the users' skills so provide the capacity to efficiently operate the system, as suggested by Ndou (2004).

- Political factors: The study also examined the influence of political factors on the egovernment initiative. Interestingly, political influence was identified as much less of a contributing factor for the system to perform successfully. The literature suggests that the nature of the e-government project's engagement with political factors should be more apparent. However, the study findings did not supported this view, in that political influence had little impact on the success of project, except in the initiation phase of the project as it needed broad political support due to its scope.

- The project alignments with the government strategic goals: the concept was supported in terms of its importance, but the portal was in a problematic situation to maintain that alignment through its operation because of late changes in national strategic plans and the strategies of the country. However, participants were confident for the future e-government project's alignment because the project has been built with the purpose of supporting government strategy.

Legal and regulatory and ICT infrastructure challenges emerged as long standing challenges which were relevant issues to the e-government initiative that can affect the success of the project. A quick response to these challenges, especially to the regulatory environment and information technology infrastructure might allow use of or enable adoption of emerging technology in the country. For example, the national 
information technology infrastructure dramatically improved since 2005 which simultaneously affected the system's adoption within the public in a positive manner.

In contrast, no visible improvements have been made around the legal and regulatory environment except for a few national ICT strategies, such as the e-Mongolia national program (2005), e-Government master plan (2005) which actually impacted negatively. Legislation and regulation issues are still hindering effective progress of the system's development. The e-government projects need to have extensive supporting frameworks and policies, for example, PKI, data sharing policies and esignature, e-transaction and cyber security laws need to be built for allowing the egovernment portal to enter into a transaction-processing stage and enable reliable and secure online data sharing.

The success factors identified from the literature and from the responses of interviewees in this research should combine to increase awareness of the factors influencing the success of the Citizen Internet Portal. Understanding the potential success factors of an e-government initiative is helpful for both practitioners and researchers where it has been confirmed by practitioners that an e-government portal is of benefit to government in achieving its policies and to users in participating in government activity.

The analysis highlighted the particular successes and challenges which might be applied to the practical implementation of future projects. Four recommendations for future implementation from both the literature review and the data analysis emerged from the study. 


\section{Section 6. Recommendations}

\section{Emerging New Trends}

Evidence from analysis of the concepts of system quality and information quality suggest that the adoption of emerging technologies, such as social networking sites including Facebook and Twitter, present a challenge to incorporate those facilities and connectivity modes into the system. In order to keep the users' interest and to maintain the balance of user satisfaction, the system needs to have both underlying system and information quality, with the application of emerging new technology trends able to be layered on top of it.

The system needs to be continually reassessed and reviewed, because technology trends are progressing at an increasing rate, and they are attracting more and more people than ever.

Also, besides social networking site trends, a mobile government trend is emerging as a part of e-government as well. The world is moving towards mobile technology which can give access to government information and services by the use of smart phones such as iPhone, Blackberry, Samsung Galaxy and so forth. E-government functions, particularly internet based applications, are creating a new direction of e-government which is mobile government, (Kushchu \& Kuscu, 2003). These internet based applications are expected to stimulate a location based information exchange and can have use for services such as fire fighting and medical emergencies. (Kushchu \& Kuscu, 2003) Therefore, the government of Mongolia needs to see the advantage of emerging technology, and to merge those technologies with what the country has already. Mobile infrastructure and citizens' use is very high in Mongolia as well, which is quite high in terms of offering those services through wireless technologies which can be a useful resource-based solution for e-government. As recognized in the consideration of the infrastructure challenge, it is essential to use the best possible infrastructure resource the country has in order to succeed in the development of egovernment solutions.

The nomadic people of rural Mongolia have adopted mobile technology within just the last ten years. The country has been measured by the Information Society Index of International Telecommunication Union (2011) at 91.1 by its mobile- cellular subscriptions per 100 
inhabitants in 2010 compared to 66.1 in 2008. (ITU, 2011). Therefore citizens' demand and effort has to be valued in terms of offering e-government services and information over rapidly increasingly used mobile services and devices.

\section{Interoperability}

As illustrated in the use, users' satisfaction and project alignment with strategic goals parts of the findings, the system is not able to go beyond what it offers now. In order to increase the demand and use of the system, practitioners agreed on an interconnected system presentation of government departments needing to be achieved. Therefore in order to step up to the next stage of development and applying emerging new trends in the e-government portal, it has to have a back end and interoperable government infrastructure where separate government subsystems come together as a core backbone network according to common standards.

E-government interoperability allows government departments to exchange and share information at a technological level. Therefore, both infrastructure and system design need to be able to operate in conjunction with other systems

\section{Legal and Regulatory Acts}

In order to make the infrastructure and system success factors real, stable and reliable government acts and regulations are critical. When a developing country, which may have only analogue telecommunication and radio spectrum regulations, enters into a digital environment without any legal regulations that would protect the online environment there is a high risk to users' interests and privacy. Government digital rights should be ensured and authenticated to determine the legitimacy of digital content, online security and transactions in an e-government context. Therefore it is highly recommended to get the acts granted and applied to the work environment. The government has an obligation to recognize and importance of and to consider the legal requirements 


\section{User Involvement}

Users' involvement helps to determine the project outcomes' successes, and helps to determine the project requirements accurately. Scholars such as Følstad, Jørgensen, \& Krogstie, (2004) say that 'involving the users in the design process of technological innovations is paramount for the success of these systems in terms of acceptance, trust and use.' (Følstad, et al, 2004, p. 11) They further suggest that 'the role of the citizen is crucial and he should be involved in the design and implementation of these large-scale systems. This will enable the citizen to have the last veto to reject something like, for instance, evoting, before it becomes a fait accompli. When users are not involved in the development of e-Government systems, democracy will be in jeopardy.' (p.14)

When looking at the current system's performance and success and at identified mistakes, the researcher found that the importance of user involvement in every level of an e-government project development has been a critical part of the system success. Users are a main focal area which needs to be concentrated on. However, the system did not involve the users' involvement adequately. It has been a big challenge for them to take the users' perspective on the system. Simply engaging users in the early stage of a project can increase user satisfaction.

\footnotetext{
'Users and citizens involvement in e-government and any other ICT project's development is essential. We have many good experiences with many other ICT systems already deployed in different organizations, the most important thing is to get involvement of citizens into the projects."
}

The participation of private sector was also very limited for the system development.

\footnotetext{
"I think another major factor for success is participation of the private sector for delivery of the e-government services, because government cannot do everything on its own. There are many ways for government to encourage public private partnership, so make it possible first, citizens, business and behalf of the government. Government must recognize its importance and start work on it”.
} 


\section{Section 7. Research Limitations}

The primary limitation of this research is that data was gathered from a relatively small number of respondents. Generally the government of Mongolia employs very few ICT specialists because of limited specialist availability and a lack of understanding of egovernment advantages. It varies depending on the how big is the system and how big is the department. Each department generally employs from one to three administrators to handle the system.

In this study, the PMIS has been operated by only one person under the Cabinet Secretary Office so she has been included. Other participants had experience of involvement in the early implementation stages of the portal. Respondents from two government departments and one independent organization were very knowledgeable and experienced in the egovernment field in the country. This background increased the preciseness of the findings.

The researcher recommends that further studies need to be conducted in this area, especially in the context of identifying the relationships between the various success factors of information system. The government and private entities are the main bodies that are expected to support the academic studies in the country. If the government of Mongolia intends to improve the transparency, poverty, national competitiveness through ICT, then they must consider the possible ways of supporting academic researchers around the egovernment and post-implementation reviews of successful e-government projects.

The study is particularly focused on the Mongolian e-government portal case, where another country might be different in terms of e-government demand and development, ICT culture and knowledge. Therefore, the results cannot be generalized to all other countries' egovernment portals. 


\section{Section 8. Conclusion}

The study examined the best practice of Mongolia using the IS success models of Delone and McLean (1992) and the 3D model, Ballentine et, al., (1996), in terms of e-government outcomes. Distance interviews were conducted in Mongolia to demonstrate the success factors of the current e-government portal PMIS. Data analysis shows that all ten success factors of the literature review have been identified by the interview respondents, suggesting a good correlation between those two sources. All these factors are essential for developing a successful e-government portal. Additionally three challenges have been illustrated.

PMIS success also provided supporting evidence that e-government portal is one of the most priority e-government initiatives for the country to achieve the national e-government goals.

Analysis of success factors also supported the belief that better performance and quality of these factors drives better utilization of information communication technology and can create many benefits for the organization and the country.

In conclusion, e-government is transforming the way government works and interacts with its citizens. Therefore, decision makers and government agencies should understand the importance of the e-government success factors as they are fundamental driving forces. The study helped to assess both the broad and detailed aspects of the e-government portal which can assist the government to take necessary actions.

Resourcing the development of increased effective government use of IT services should be a priority. P. Dunleavy, et al. 2006 stated that 'If relevant current computer systems do not allow it, there is now no practicable way in which governments can collect broad-based taxation or distribute welfare benefits or regulate immigration into their country on a mass scale without first implementing the necessary IT changes. They no longer have the personnel or the expertise to accomplish these tasks without the IT.' (p.26) 


\section{References}

Ballantine, J., Levy, M., Martin, A., Munro, I., Powell, P., \& Bonner, M. (1996). The 3-D model of information systems success: the search for the dependent variable continues. Information Resources Management Journal, 9, 5-15.

Benbasat, I., \& Zmud, R. W. (2003). The identity crisis within the IS discipline: Defining and communicating the discipline's core properties. MIS Quarterly, 183-194.

Burke, M. E. (2007). Making choices: Research paradigms and information management. Practical applications of philosophy in IM research. Library Review, 56(6), 476-484

Carr, W., \& Kemmis, S. (1986). Becoming critical: education, knowledge and action research. Melbourne, Australia : Deakin University Press

Cegielski, C. G., Reithel, B. J., \& Rebman, C. M. (2005). Emerging information technologies: Developing a timely IT strategy. Communications of the ACM, 48(8), 113-117

Chadwick, A. (2006). Internet Politics: States, Citizens, and New Communication Technologies, pp.177-203 Oxford, England: Oxford University Press.

Chua, W. F. (1986). Radical developments in accounting thought. Accounting Review, 61 (4), 601-632

CIA (2011) CIA - The World Factbook. Retrieved from https://www.cia.gov/library/publications/the-world-factbook/geos/mg.html

Criado, J. I., \& Ramilo, M. C. (2003). E-government in practice: an analysis of web site orientation to the citizens in Spanish municipalities. International Journal of Public Sector Management, 16(3), 191-218.

Davaakhuu, D. \& Delgermaa, A. (2000). Terminal Project Report MON97/122 ICT for SHD Project (No. MON97/122). Ulaanbaatar: Government of Mongolia/UNDP.

Delone, W. H. \& McLean, E. R. (1992). Information systems success: the quest for the dependent variable. Information Systems Research, 3(1), 60-95.

Delone, W. H. \& McLean, E. R. (2003). The Delone and McLean model of information systems success: A ten-year update. Journal of Management Information Systems, 19(4), 9-30.

Detlor, B. \& Finn, K. (2002). Towards a framework for government portal design: the government, citizen and portal perspectives. Electronic government: Design, applications, and management, 97-117. 
Dongier, P. National e-Government Portals. Retrieved from http://web.worldbank.org/WBSITE/EXTERNAL/TOPICS/EXTINFORMATIONAN DCOMMUNICATIONANDTECHNOLOGIES/EXTEDEVELOPMENT/0,,contentM DK:21326015 pagePK:148956 piPK:216618 theSitePK:559460,00.html

Dunleavy, P., Margetts, H., Bastow, S., \& Tinkler, J. (2006). New public management is dead: long live digital-era governance. Journal of Public Administration Research and Theory, 16 (3).

Elnaghi, M., Alshawi, S., \& Missi, F. (2007). A leadership model for e-government transformation. Proceedings of European and Mediterranean Conference on Information Systems 2007, Polytechnic University of Valencia, Spain.

Fang, Z. (2002). E-government in digital era: concept, practice, and development.

International Journal of The Computer, The Internet and Management, 10(2), 1-22.

Fahnbulleh, N. (2005). The future of electronic government. Futurics, 29 (1/2), 7-12

Foley, P. \& Alfonso, X. (2009). e-government and the transformation agenda. Public Administration, 87(2), 371-396.

Følstad, A., Jørgensen, H. D., \& Krogstie, J. (2004). User involvement in e-Government development projects. In Proceedings of the Third Nordic Conference on HumanComputer Interaction, Tampere, Finland.

Fontana, A., \& Frey, J. H. (1994). Interviewing: The art of science. In Denzin, Y. L. (ed.) The Handbook of Qualitative Research. Thousand Oaks, CA : Sage

Gable, G. G., Sedera, D. \& Chan, T. (2008). Re-conceptualizing information system success: the IS-impact measurement model. Journal of the Association for Information Systems, 9(7), 18.

Gant, J. P. \& Gant, D. B. (2002). Web portal functionality and state government e-service in Proceedings of the $35^{\text {th }}$ Hawaii International Conference on System Sciences - 2002. Los Alamitos, CA: IEEE CS Press.

Gil-García, J. R. \& Pardo, T. A. (2005). E-government success factors: Mapping practical tools to theoretical foundations. Government Information Quarterly, 22(2), 187-216.

Government Document (2011). Tender Bid Document, ICTPA

Grönlund, Å. \& Horan, T. A. (2005). Introducing e-gov: history, definitions, and issues. Communications of the Association for Information Systems, 15(39), 713-729.

Gupta, M., \& Jana, D. (2003). E-government evaluation: A framework and case study. Government Information Quarterly, 20(4), 365-387.

Hagedorn, K. (2000). The Information Architecture Glossary. Ann Arbor, MI: Argus Associates 
Heeks, R. (2003). Most e-government-for-development projects fail: how can risks be reduced? Manchester, England: IDPM

Heeks, R. (2005). e-Government as a Carrier of Context. Journal of Public Policy, 25(1), 5174.

Hu, Y., Xiao, J. H., Pang, J. F. \& Xie, K. (2005). A research on the appraisal framework of egovernment project success. ICEC '05 Proceedings of the $7^{\text {th }}$ International Conference on Electronic Commerce. New York, NY: ACM

ICTA, (2005) E-Government Master Plan in Mongolia. Ulaanbaatar, Mongolia : ICTA

Information Communication Technology and Post Authority (2010). Design-Build-Finance Operate-Transfer a Citizens' Internet Portal, Government Administrative Intranet and Virtual Private Network as a Public Private Partnership in E-Government. Retrieved from http://www.ictpa.gov.mn/en/?p=116

International Finance Corporation and the World Bank. (2011) Retrieved October 10, 2011, from http://www.doingbusiness.org/data/exploreeconomies/mongolia/

IPPP. (2009). Public-Private Partnerships in E-Government: Handbook. Retrieved from http://www.infodev.org/en/Project.40.html

Iribarren, M., Concha, G., Valdes, G., Solar, M., Villarroel, M., Gutiérrez, P., \& Vasquez, A.. (2008). Capability Maturity Framework for eGovernment: A Multi-dimensional Model and Assessing Tool. Electronic Government, 136-147.

ITU. (2011). Measuring the Information Society. Geneva: International Telecommunication Union.

Joseph, R. C. \& Kitlan, D. P. (2008) Key issues in e-government and public administration. in Garson, G. D. \& Khosrow-Pour, M. (eds.) (2008).Handbook of Research on Public Information Technology, Vol.1, Hershey, PA: IGI Global.

King, W. R. \& Teo, T. S. H. (1997). Integration between business planning and information systems planning: validating a stage hypothesis. Decision Sciences, 28 (2), 279-308.

Kushchu, I., \& Kuscu, H. (2003). From E-government to M-government: Facing the Inevitable. In The Proceedings of European Conference on e-Government (ECEG 2003), Trinity College, Dublin, Ireland.

Layne, K., \& Lee, J. (2001). Developing fully functional E-government: A four stage model. Government Information Quarterly, 18(2), 122-136.

Myers, M. D. \& Avison, D. (2002). An Introduction to Qualitative Research in Information Systems In Qualitative Research in Information Systems: A reader. Thousand Oaks, CA : Sage 
Ndou, V. D. (2004). E-Government for developing countries: Opportunities and challenges. The Electronic Journal on Information Systems in Developing Countries,, 18(1), 1-24

NSO (2011). National Statistics Office of Mongolia. Retrieved from http://www.nso.mn/v3

Orlikowski, W. J., \& Baroudi, J. J. (1991). Styding Information Technology in Organizations: Research Approaches and Assumptions. Information Systems Research 2 (1) 1-28

Prybutok, V. R., Zhang, X., \& Ryan, S. D. (2008). Evaluating leadership, IT quality, and net benefits in an e-government environment. Information \& Management, 45(3), 143 152.

Reffat, R. (2003). Developing a successful e-government. In The Proceedings of the Symposium on e-Government: Opportunities and Challenge, Muscat Municipality, Oman.

Robey, D. \& Markus, M. L. (1998). Beyond rigor and relevance: producing consumable research about information systems. Information Resources Management Journal, $11(1), 7-15$.

Saldhana, A. (2007). Secure E-Government Portals. Paper presented at the W3C Workshop on e-Government and the Web. Retrieved from http://www.w3.org/2007/06/eGovdc/papers/

Sambuu, U., Tudevdagva, U., \& Erdene, G. (2008). e-governance initiatives in Mongolia in ICEGOV '08, Proceedings of the $2^{\text {nd }}$ International Conference on Theory and Practice of Electronic Governance. New York, NY: ACM

Seaman, C. B. (1999). Qualitative methods in empirical studies of software engineering. Software Engineering, IEEE Transactions on, 25(4), 557-572.

Sukhbaatar, B. \& Odgerel, U. (2005). A study on e-government policy in Mongolia. Information and Telecommunication Technologies, 2005. APSITT 2005 Proceedings. $6^{\text {th }}$ Asia-Pacific Symposium. doi: 10.1109/APSITT.2005.203666.

Ulziikhutag, O. \& Sukhbaatar, S. (2006). Mongolia: e-Government Key Challenges to Enhance Citizen Participation. Retrieved from http://unpan1.un.org/intradoc/groups/public/documents/other/unpan024832.pdf

UN. (2010). United Nations E-Government Survey 2010: Leveraging e-government at a time of financial and economic crisis. Retrieved from http://unpan1.un.org/intradoc/groups/public/documents/UN-DPADM/UNPAN038853.pdf

Walsham, G. (2006). Doing interpretive research. European Journal of Information Systems, $15,320-330$.

Wimmer, M. A. (2001). Integrated service modelling for online one-stop government. Electronic Markets, 12(3), 149-156 
World Bank (2011) Data Lower middle income retrieved from http://data.worldbank.org/income-level/LMC

Yin, R. K. (1994) Case study research: design and methods. Applied Social Research methods Series, 5. ?? : Sage 


\section{Appendix 1. Interview Questions}

1. Would you please introduce yourself?

2. First we are going to discuss the outcome of the current e-government portal.

3. What was your involvement in the e-government portal project?

4. How would you evaluate the performance of the current PMIS portal site towards the goals?

5. What kind of services does the current portal deliver? What tasks does it support?

6. What are the main barriers to the success of the current portal?

7. How would you describe the citizens' use of the current portal?

8. How satisfied are citizens with the current portal? How would you define the user satisfaction? How is satisfaction measured?

9. Do you feel the current portal is aligned with e-government strategy? If not, why not?

10. How has the social and political context affected the success of the current portal?

11. How has the technology solution affected the performance of the current portal?

12. Do you think system selection has affected the performance of the current portal?

13. How would you assess the importance of users skills for the success (or otherwise) of the current portal?

14. How has the support of a project champion influenced the current portal project's outcome?

15. How has project management affected the current portal project's outcome?

16. How has the quality of the data affected the current portal project's outcome?

17. How has the quality of the IS staffs (skill and experience) affected the current portal project's outcome?

Next we are going to discuss your overall view of the success of an e-government portal?

18. What are the goals for an e-government portal?

19. How do you evaluate the current government performance in terms of improving egovernment services?

20. Do you think the government can achieve e-government goals through an egovernment portal?

21. Are there any other factors that you believe would influence delivery of the service? 
22. How would you describe the benefits of an e-government portal?

23. What steps need to be taken in order to successfully deliver an e-government portal that achieves these benefits?

24. Are there any other factors e-government portal successes in Mongolia that you want to discuss? 